\title{
Periodic input of dust over the Eastern Carpathians during the Holocene linked with Saharan desertification and human impact
}

\author{
Jack Longman $^{1}$, Daniel Veres ${ }^{2}$, Vasile Ersek ${ }^{1}$, Ulrich Salzmann ${ }^{1}$, Katalin Hubay ${ }^{3}$, Marc Bormann ${ }^{4}$, \\ Volker Wennrich $^{5}$, and Frank Schäbitz ${ }^{4}$ \\ ${ }^{1}$ Department of Geography, Northumbria University, Newcastle-Upon-Tyne, UK \\ ${ }^{2}$ Romanian Academy, Institute of Speleology, Clinicilor 5, Cluj-Napoca, Romania \\ ${ }^{3}$ Hungarian Academy of Science - Institute for Nuclear Research, Hertelendi Laboratory of Environmental Studies, \\ Bem tér 18/C, 4026 Debrecen, Hungary \\ ${ }^{4}$ Institute of Geography Education, University of Cologne, 50931 Cologne, Germany \\ ${ }^{5}$ Institute of Geology and Mineralogy, University of Cologne, 50674 Cologne, Germany
}

Correspondence to: Jack Longman (jack.longman@ northumbria.ac.uk) and Daniel Veres (daniel.veres@ubbcluj.ro)

Received: 17 January 2017 - Discussion started: 25 January 2017

Revised: 21 April 2017 - Accepted: 13 June 2017 - Published: 18 July 2017

\begin{abstract}
Reconstructions of dust flux have been used to produce valuable global records of changes in atmospheric circulation and aridity. These studies have highlighted the importance of atmospheric dust in marine and terrestrial biogeochemistry and nutrient cycling. By investigating a $10800-$ year-long paleoclimate archive from the Eastern Carpathians (Romania) we present the first peat record of changing dust deposition over the Holocene for the CarpathianBalkan region. Using qualitative (X-ray fluorescence (XRF) core scanning) and quantitative inductively coupled plasma optical emission spectrometer(ICP-OES) measurements of lithogenic $(\mathrm{K}, \mathrm{Si}, \mathrm{Ti})$ elements, we identify 10 periods of major dust deposition between 9500-9200, 8400-8100, $7720-7250,6350-5950,5450-5050,4130-3770,3450-$ $2850,2000-1450,800-620$, and 60 cal yr BP to present. In addition, we used testate amoeba assemblages preserved within the peat to infer local palaeohydroclimatic conditions. Our record highlights several discrepancies between eastern and western European dust depositional records and the impact of highly complex hydrological regimes in the Carpathian region. Since 6100 cal yr BP, we find that the geochemical indicators of dust flux have become uncoupled from the local hydrology. This coincides with the appearance of millennial-scale cycles in the dust input and changes in geochemical composition of dust. We suggest that this is indicative of a shift in dust provenance from local-regional (likely loess-related) to distal (Saharan) sources, which coin-
\end{abstract}

cide with the end of the African Humid Period and the onset of Saharan desertification.

\section{Introduction}

Atmospheric dust plays a major role in oceanic and lacustrine biogeochemistry and productivity (Jickells, 2005) by providing macronutrients to these systems (Mahowald et al., 2010). Furthermore, climatically dust plays a role in forcing precipitation (Ramanathan, 2001; Yoshioka et al., 2007) and in moderating incoming solar radiation. As such, reconstructions of past dust flux are an important tool to understand Holocene climate variability, biogeochemical cycles, and the planet's feedback to future changes in atmospheric dust loading.

The link between atmospheric circulation patterns and dust input has been studied intensively (Allan et al., 2013; Kylander et al., 2013a; Marx et al., 2009; Le Roux et al., 2012) with clear evidence of climate variations linked with the dust cycle (Goudie and Middleton, 2006). Generally, dust is produced in arid zones (Grousset and Biscaye, 2005) and may be transported thousands of miles before deposition (Grousset et al., 2003). In addition, dust input into the atmosphere can increase significantly during droughts (e.g. Miao et al., 2007; Notaro et al., 2015; Sharifi et al., 2015). As such, fluctuations in dust loading may be indicative of both regional drying and long-distance transport (Le Roux et al., 2012). 
Hydroclimatic fluctuations had a significant effect on the development of civilisations throughout the Holocene (Brooks, 2006; deMenocal, 2001; Sharifi et al., 2015), especially on those that relied heavily on agriculture and pastoralism, as was the case in the Carpathian-Balkan region (Schumacher et al., 2016). To understand the impact hydroclimatic changes had on the population of an area of such importance to European history, high-resolution palaeoclimate and palaeohydrological records are needed. This is especially important in the Carpathian region, given the extensive loess cover in the area (Marković et al., 2015) - a fundamental factor in sustaining high agricultural production. Additionally, the sensitivity of loess to moisture availability and water stress during dry periods may turn this region and other surrounding loess belts into major dust sources (Kok et al., 2014; Rousseau et al., 2014; Sweeney and Mason, 2013). This is particularly true under semi-arid (Edri et al., 2016), or agriculturally altered conditions (Korcz et al., 2009), as is the case with the major dust fields of eastern Eurasia (Buggle et al., 2009; Smalley et al., 2011; Újvári et al., 2012). Thus, the dust influx into the Carpathian-Balkan region should be extremely sensitive to relatively small changes in precipitation rates. This hydroclimatic sensitivity is enhanced due to the fact that the Carpathians and the surrounding lowlands are located at a confluence of three major atmospheric systems: the North Atlantic, the Mediterranean, and the Siberian High (Obreht et al., 2016). Indeed, research appears to indicate that the climate in Romania is controlled, at least in part, by North Atlantic Oscillation (NAO) fluctuations (Bojariu and Giorgi, 2005; Bojariu and Paliu, 2001) but it is yet unclear how this relationship evolved in the past (Haliuc et al., 2017).

Multi-proxy and high-resolution studies of palaeoenvironmental changes in the region are still scarce, with most focusing on reconstructing past vegetation changes (e.g. Feurdean et al., 2012). More recently, testate amoeba (TA) (Schnitchen et al., 2006; Feurdean et al., 2015), pollen and diatoms (Magyari et al., 2009, 2013; Buczkó et al., 2013), and macrofossils (Gałka et al., 2016) have been utilised to elucidate the history of hydroclimatic variability in the region. What is evident from these studies is the high inter-site variability, with clear disagreements on timing and extent of wet and dry periods within a relatively small spatial distribution (e.g. two spatially close sites displaying differing precipitation trends as reported in Feurdean et al., 2008). It is possible that this variability reflects only site-related (including chronological) uncertainties or is an indicator of the impact of location at the contact of several climatic zones (Obreht et al., 2016). To determine this, the impact of different modes of atmospheric (and moisture) circulation patterns and their imprint within paleoclimate archives must be investigated through better regional coverage following high-resolution multi-proxy approaches (e.g. Longman et al., 2017; Haliuc et al., 2017).

Our research provides a record of periodic dry and/or dusty periods in eastern Europe as indicated by reconstructed dust input using an ombrotrophic bog from the Romanian Carpathians (Fig. 1). As the only source of clastic material deposited within ombrotrophic bogs is via atmospheric loading, such records have been used convincingly as archives of dust deposition over the Holocene in western Europe and Australia (Allan et al., 2013; Kylander et al., 2013a; Marx et al., 2009, 2010; Le Roux et al., 2012). To produce records of dust and/or hydroclimate variability, both inorganic (Allan et al., 2013; Ross-Barraclough and Shotyk, 2003; Shotyk, 2002) and organic (Booth et al., 2005; Lamentowicz et al., 2008; Morris et al., 2015; Swindles et al., 2010) proxies may be utilised (see Chambers et al., 2012) for a review).

Here we present the first record of dust input over the Carpathian Mountains, documenting changes in dust flux, source, and intensity of deposition using the downcore lithogenic element concentrations from the Mohos ombrotrophic bog profile. The record covers 10800 years of deposition over $9.5 \mathrm{~m}$ of peat, providing a valuable highresolution record for this region. Our research utilises both organic and inorganic proxies, with a high-resolution geochemical record of lithogenic elements $(\mathrm{Ti}, \mathrm{Si}$, and $\mathrm{K})$, presented alongside the bog surface wetness as reconstructed using testate amoeba to understand dust source changes and the link between regional and extra-regional hydroclimate variability and dust.

\section{Materials and methods}

\subsection{Geographical setting}

The Mohos peat bog $\left(25^{\circ} 55^{\prime} \mathrm{E}, 46^{\circ} 05^{\prime} \mathrm{N}, 1050 \mathrm{~m}\right.$ altitude; Fig. 1) is located in the Eastern Carpathians, Romania, in the Ciomadul volcanic massif (Fig. 1). The Sphagnumdominated bog covers some 80 ha and occupies an infilled volcanic crater. There is no riverine inflow, which means that inorganic material deposited within the bog is almost exclusively derived via direct atmospheric transport. The climate is temperate continental, with average annual temperatures of $15^{\circ} \mathrm{C}$ and precipitation of $800 \mathrm{~mm}$ (Kristó, 1995). Surrounding vegetation is typical of this altitude in the Carpathians (Cristea, 1993), the bog being located at the upper limit of the beech forest, with spruce also found on surrounding slopes. Vegetation on the bog itself is diverse, with common occurrences of Pinus sylvestris, Alnus glutinosa, and Betula pubescens, alongside various Salix species (Pop, 1960; Tanţau et al., 2003).

The Mohos crater is related to volcanic activity from the Ciomadul volcano, which last erupted roughly 29.6 cal kyr BP in the neighbouring younger crater currently occupied by the Lake Sfânta Ana (Harangi et al., 2010; Karátson et al., 2016; Magyari et al., 2014; Wulf et al., 2016). The surrounding geology is dominated by andesites and dacites, occasionally capped by pyroclastic deposits and a thick soil cover. 

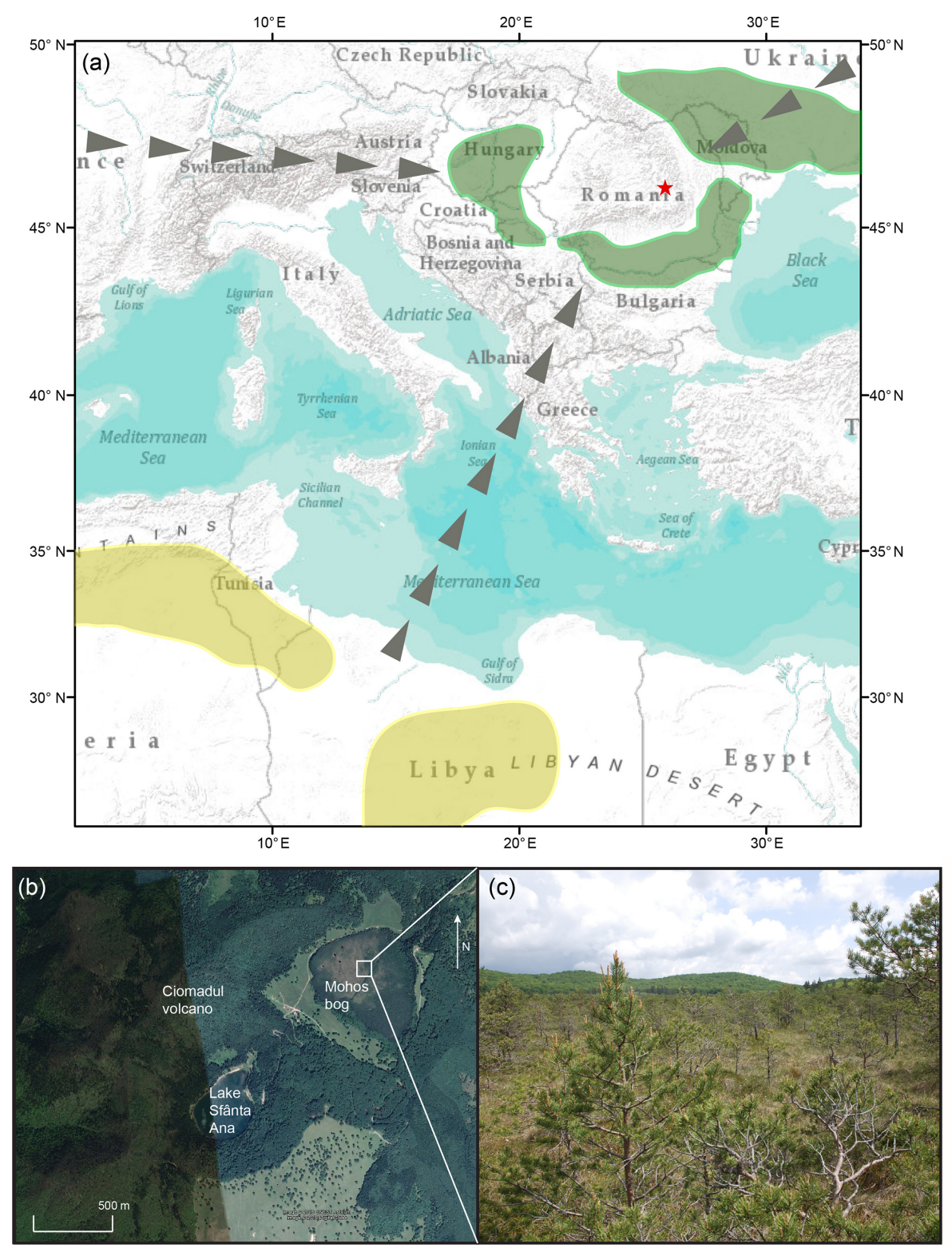

Figure 1. (a) Map of the Carpathian-Balkan region indicating location of Mohos peat bog (red star) in the southern Eastern Carpathian Mountains. Predominant wind directions relating to air circulation patterns in the area are indicated by black arrows. Major Saharan dust source areas are indicated in yellow (Scheuvens et al., 2013) and local loess fields (including loess-derived alluvium) in green (Marković et al., 2015). (b) Map of Mohos and neighbouring Lake Sfânta Ana, from Google Earth 6.1.7601.1 (10 June 2016). Harghita County, Romania, $46^{\circ} 05^{\prime} \mathrm{N}, 25^{\circ} 55^{\prime} \mathrm{E}$, eye altitude $3.06 \mathrm{~km}$, CNES/Astrium, DigitalGlobe 2016, http://www.google.com/earth/index.html. Coring location within white box. (c) Photo of Mohos bog at the coring location with the crater rim visible in the distance.

\subsection{Coring}

A Russian peat corer was used to recover a $950 \mathrm{~cm}$ long peat sequence from the middle part of Mohos bog. The material consists mainly of Sphagnum peat and lacustrine sediments in the lowermost part. Upon recovery, the material was wrapped in clingfilm, transported to the laboratory, described, imaged, and subjected to further analyses. The core was stored at $3{ }^{\circ} \mathrm{C}$.

\subsection{Sedimentological parameters}

Loss on ignition (LOI) was performed on $\sim 1 \mathrm{~g}$ (exactly $1 \mathrm{~cm}^{3}$ ) of wet peat, sampled at $2 \mathrm{~cm}$ resolution. The peat was dried overnight at $105^{\circ} \mathrm{C}$ prior to ignition at $550^{\circ} \mathrm{C}$ for $4 \mathrm{~h}$. Weight loss after this combustion was used to calculate combusted organic material, followed by further combustion at $950^{\circ} \mathrm{C}$ for $2 \mathrm{~h}$ to calculate total carbon content following carbonate removal (Heiri et al., 2001). The dry bulk density was 
determined from the known volume and the dry weight prior to combustion.

\subsection{Micro-XRF and multi-sensor core logger (MSCL) core scanning}

Non-destructive X-Ray fluorescence (XRF) analysis was performed using an Itrax core scanner equipped with a Si drift chamber detector (Croudace et al., 2006) at the University of Cologne (Institute of Geology and Mineralogy). The analytical resolution employed a $2 \mathrm{~mm}$ step size and $20 \mathrm{~s}$ counting time using a $\mathrm{Cr} \mathrm{X}$-ray tube set to $30 \mathrm{kV}$ and $30 \mathrm{~mA}$. The method allows for a wide range of elements to be analysed, from which we have selected $\mathrm{Ti}, \mathrm{K}$, and $\mathrm{Si}$ for further interpretation. To allow for better visibility, all XRF data sets were smoothed using a nine-point running average. Due to the methodological nature of XRF core scanning, the data are presented as counts per second (cps) and are therefore considered as semi-quantitative. To ensure that the impact of sedimentological variables, including density, high organic matter, and water content, is taken into account, the raw cps values have been normalised with respect to total (incoherent + coherent) scattering (Kylander et al., 2011, 2013b).

\subsection{ICP-OES}

To perform quantitative analysis of elements to allow inference of past dust flux, as well as to validate the Itrax data, ICP-OES analysis was carried out on 105 samples of $1 \mathrm{~cm}^{3}$ of sediment, roughly every $10 \mathrm{~cm}$, through the entire core. These samples were dried at $105^{\circ} \mathrm{C}$ overnight before homogenising using a pestle and mortar and were then subjected to a mixed acid $\left(\mathrm{HNO}_{3}: \mathrm{HCl}: \mathrm{HF}\right)$ total digestion (adapted from Krachler et al., 2002) for $40 \mathrm{~min}$ in a MARS accelerated reaction system. The solution was then analysed using a PerkinElmer Optima 8000 ICPOES system at Northumbria University. To monitor potential instrumental drift, an internal standard (1 ppm Sc) was added to all samples and analysed alongside Ti. In addition, two certified reference materials (CRMs) were digested and analysed throughout the runs (Montana soil 2711 and NIMT/UOE/FM/001). Recoveries for both CRMs were good for Ti, with average values of 85 and $79 \%$. Blanks with negligible Ti contamination were run alongside the samples and CRMs.

\subsection{Calculating dust flux}

The dust flux delivered to an ombrotrophic bog via atmospheric loading may be calculated using the concentration of a lithogenic element, such as Ti (Allan et al., 2013). Using the averaged occurrence of $\mathrm{Ti}$ in the upper continental crust (upper continental crust (UCC) values from Wedepohl, 1995), the density of the peat, and the peat accumulation rate
(PAR), the following formula may be used:

$$
\begin{aligned}
\text { Dust flux } & \left(\mathrm{g} \mathrm{m}^{-2} \mathrm{yr}^{-1}\right)=\left(\frac{[\mathrm{Ti}]_{\text {sample }}}{[\mathrm{Ti}]_{\mathrm{UCC}}}\right) \\
& \times \text { density } \times \text { PAR } \times 10000 .
\end{aligned}
$$

\subsection{Palaeoecological indicators}

A total of 44 samples of roughly $1 \mathrm{~cm}^{3}$ each were sampled along the peat profile for testate amoeba analysis. The bulk samples were disaggregated and sieved according to Booth et al. (2010), prior to mounting in water on slides. Two tablets of Lycopodium spores of known value were added prior to disaggregation to allow for calculation of test density. For each sample at least 150 tests were counted, with identification of taxa following Charman et al. (2000). For interpretation, two methods of determining wet and dry local depositional environments based on changes in testate amoeba assemblages were used. Firstly, a transfer function (Schnitchen et al., 2006) already applied to Carpathian bogs was used to reconstruct past variations in the depth of the water table (DWT). Secondly, the main taxa were grouped according to their affinity for wet or dry conditions according to Charman et al. (2000) and plotted as a function of percentage.

\subsection{Chronology}

The age model for the Mohos peat record is based on 16 radiocarbon dates on bulk peat (collected over less than $1 \mathrm{~cm}$ depth interval per sample) consisting only of Sphagnum moss remains (Table 1). These analyses were performed via EnvironMICADAS accelerator mass spectrometry (AMS) at the Hertelendi Laboratory of Environmental Studies (HEKAL), Debrecen, Hungary, using the methodology outlined in Molnár et al. (2013). The ${ }^{14} \mathrm{C}$ ages were converted into calendar years using the IntCal13 calibration curve (Reimer et al., 2013), and an age-depth model (see Fig. 2) was generated using Bacon (Blaauw and Christen, 2011).

\subsection{Wavelet analysis}

Continuous Morlet wavelet transform was used to identify non-stationary cyclicities in the data (Grinsted et al., 2004; Torrence and Compo, 1998). For this analysis, the lithogenic normalised elemental data from Itrax measurements ( Ti, K, and $\mathrm{Si}$ ) was interpolated to equal time steps of 4 years using a Gaussian window of 12 years.

\subsection{Grain size}

In an effort to indicate distal versus local inputs to the bog via the dust particle size, grain size analysis was attempted using a Malvern Mastersizer 2000. Unfortunately, as also observed in previous studies (Kylander et al., 2016), due to the lack of available sample material, and low minerogenic matter (and correspondingly high organic matter) present in the samples, 

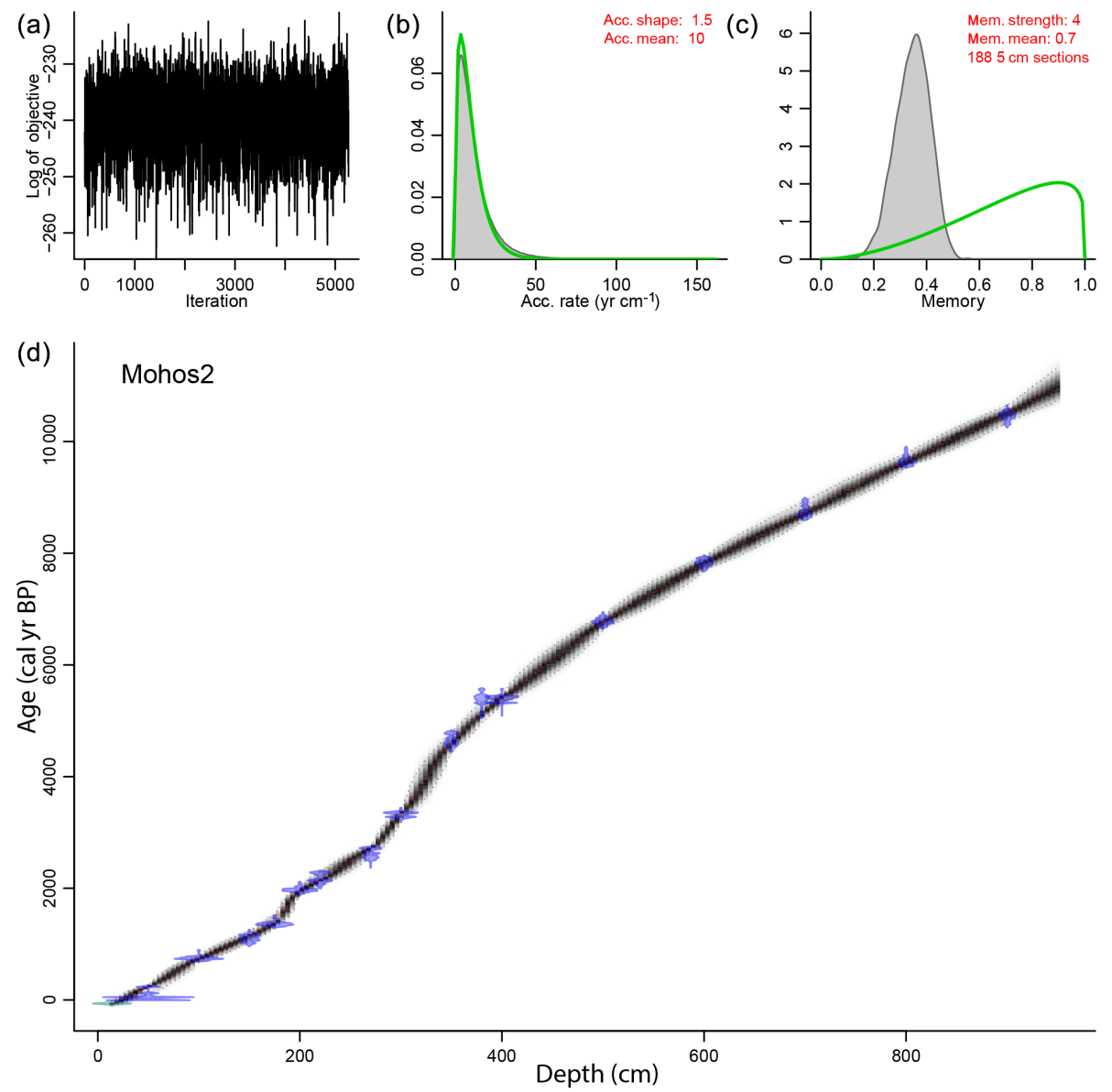

Figure 2. Age-depth model of Mohos peat record, as determined via Bacon (Blaauw and Christen, 2011). (a) Graph indicates Markov chain Monte Carlo iterations. Also in (b) and (c) are prior (green line) and posterior (grey histogram) distributions for the accumulation rate (b) and memory (c). For panel (d), calibrated radiocarbon ages are in blue. The age-depth model is outlined in grey, with darker grey indicating more likely calendar ages. Grey stippled lines show $95 \%$ confidence intervals, and the red curve indicates the single best model used in this work.

satisfactory obscuration values were not achieved for most analyses.

\section{Results}

\subsection{Age model and lithology}

The Mohos peat profile is $950 \mathrm{~cm}$ long and reaches the transition to the underlying basal limnic clay (Tanţau et al., 2003). Between 950 and $890 \mathrm{~cm}$ the record is composed of organic detritus (gyttja) and Carex peat deposited prior to the transition from a wetland into a bog at roughly $10330 \mathrm{yr}$ BP. From $890 \mathrm{~cm}$ upwards, the core is primarily Sphagnum-dominated peat. The age-depth model indicates that the Mohos peat record covers almost 10800 years of deposition, with the uppermost layer (growing moss) of the peat dating to 2014. Age model uncertainties range from 20 years in the uppermost sections to 150 years at the base of the core. Thus, the resolution for Itrax data average $\sim 5 \mathrm{yr} \mathrm{sample}^{-1}$ and for ICP-OES is roughly $100 \mathrm{yr}$ sample $^{-1}$, respectively. The tes- tate amoeba resolution is roughly $200 \mathrm{yr} \mathrm{sample}^{-1}$. In the following, all quoted ages are given in calibrated years before present (cal yr BP).

\subsection{Dust indicators}

\subsubsection{Ti, $\mathrm{K}$, and $\mathrm{Si}$}

Similar trends for the lithogenic elements $\mathrm{Ti}$ and $\mathrm{Si}$ and the mobile element $\mathrm{K}$ are visible in the record (Fig. 3), with 10 main zones of higher counts above typical background values present. Such zones are identified as an increase in two or more of the elements above the background deposition $(\mathrm{K}>0.001, \mathrm{Si}>0.001$, and $\mathrm{Ti}>0.004$; see dashed line in Fig. 3). These intervals are further discussed as reflecting major dust deposition events and are referenced in the remainder of the text using the denotation D01-D10 (Fig. 3). Two exceptions, at the base of the core, close to the transition from lake to bog, and the last 1000 years, due to high noise, are not highlighted. The lithogenic, and there- 
Table 1. Radiocarbon dates used to build the age model for the Mohos peat record.

\begin{tabular}{lrrrl}
\hline Lab ID & Depth & ${ }^{14} \mathrm{C}$ age $(\mathrm{yr} \mathrm{BP} \pm 1 \sigma)$ & Calibrated age $($ cal yr BP $\pm 2 \sigma)$ & Dated material \\
\hline DeA-8343 & 50 & $37 \pm 18$ & $37-65$ & Bulk peat \\
DeA-8344 & 100 & $838 \pm 19$ & $700-785$ & Bulk peat \\
DeA-10111 & 150 & $1174 \pm 28$ & $1049-1179$ & Bulk peat \\
DeA-10112 & 175 & $1471 \pm 26$ & $1309-1399$ & Bulk peat \\
DeA-8345 & 200 & $2022 \pm 21$ & $1921-2007$ & Bulk peat \\
DeA-10137 & 225 & $2155 \pm 27$ & $2048-2305$ & Bulk peat \\
DeA-10138 & 280 & $2530 \pm 28$ & $2495-2744$ & Bulk peat \\
DeA-8346 & 300 & $3112 \pm 23$ & $3249-3383$ & Bulk peat \\
DeA-10139 & 350 & $4110 \pm 31$ & $4523-4713$ & Bulk peat \\
DeA-10140 & 380 & $4641 \pm 54$ & $5282-5484$ & Bulk peat \\
DeA-8347 & 400 & $4638 \pm 26$ & $5372-5463$ & Bulk peat \\
DeA-10141 & 500 & $5949 \pm 36$ & $6677-6861$ & Bulk peat \\
DeA-10142 & 600 & $6989 \pm 43$ & $7785-7867$ & Bulk peat \\
DeA-8348 & 700 & $7909 \pm 33$ & $8600-8793$ & Bulk peat \\
DeA-10143 & 800 & $8687 \pm 45$ & $9539-9778$ & Bulk peat \\
DeA-8349 & 900 & $9273 \pm 36$ & $10369-10571$ & Bulk peat \\
\hline
\end{tabular}

fore soil- and rock-derived, $\mathrm{Ti}$ and $\mathrm{Si}$ have previously been used as proxies for dust input (e.g. Allan et al., 2013; Sharifi et al., 2015), whilst $\mathrm{K}$ covaries with $\mathrm{Si}\left(R^{2}=0.9945\right)$. Thus, controlling factors in their deposition must be similar. For these elements, the periods with inferred non-dust deposition are characterised by values approaching the detection limit $(150,15$, and $40 \mathrm{cps})$. A short period of very high values for all elements $(10000,1300$, and $8000 \mathrm{cps})$ is observed between 10800 and $10500 \mathrm{cal}$ yr BP (not shown on diagram), reflecting the deposition of clastic sediments within the transition from lake to bog at the onset of the Holocene. Zones of elevated values (D1-D5), with average cps values of roughly $\mathrm{Ti}=300, \mathrm{Si}=30$, and $\mathrm{K}=100$ and persisting for several centuries each, occur sporadically throughout the next 6000 years of the record, between 9500-9200, 8400-8100, 7720-7250, 6350-5900, and $5450-5050$ cal yr BP (Fig. 3). Similarly long periods, but with much higher element counts $(\mathrm{Ti}=800, \mathrm{Si}=60$ and $\mathrm{K}=200 \mathrm{cps}$ ), occur between 413-3770, 3450-2850, and 2000-1450 cal yr BP (D6-8). Two final, short (roughly 100year duration) but relatively large peaks (D9-10) may be seen in the last 1000 years between 800-620 cal yr BP (with values of $\mathrm{Ti}=300, \mathrm{Si}=40$, and $\mathrm{K}=100 \mathrm{cps}$ ) and $60 \mathrm{cal} \mathrm{yr} \mathrm{BP}$ to present $(\mathrm{Ti}=300, \mathrm{Si}=80$, and $\mathrm{K}=400 \mathrm{cps})$.

\subsubsection{Dust flux}

Using the quantitative ICP-OES values of $\mathrm{Ti}$ (in parts per million) and Eq. (1), the dust flux can be calculated (Fig. 3). The ICP-OES Ti record shows very good correlation with the Ti data derived through Itrax analysis. To facilitate comparison, we put both records on the same timescale using a Gaussian interpolation with 100 -year time steps and a 300 -year window. Pearson's $r=0.2649$, with a $p$ value of $<0.001$, indicative of a significant correlation (see Supplement 4). This further indicates the reliability of the XRF core scanning method even for such highly organic sediments (as already suggested by Poto et al., 2014) and validates its usage as proxy for deriving dust flux (Fig. 3).

It must be noted here that using $\mathrm{Ti}$ alone in dust flux calculations does not allow for reconstruction of all minerals related to dust deposition. Ti, which is lithogenic and conservative, is a major component in soil dust, particularly within clay minerals (Shotyk et al., 2002), but may not be associated with other dust-forming minerals, including phosphates, plagioclase, and silicates (Kylander et al., 2016), although our records of $\mathrm{K}$ and Si may help indicate changes in deposition rates of these minerals (see Mayewski and Maasch, 2006). As a result, we are unable to infer specific mineral-related changes in the composition of dust. However, Ti alone will record changes in the intensity of deposition of the main dustforming minerals (Sharifi et al., 2015; Shotyk et al., 2002), and variations in $\mathrm{K}$ and $\mathrm{Si}$ (particularly with local $\mathrm{K}$ - and Si-rich dacites, which are a possible dust source) may further indicate the influx of minerals that are not associated with Ti. Such an approach has been successfully applied to studies of changing dust influx (e.g. Allan et al., 2013; Sapkota et al., 2007; Sharifi et al., 2015), with each study able to identify periods of high and low dust deposition from Ti-derived dust flux alone.

The Ti-derived dust flux for most of the record is below $1 \mathrm{~g} \mathrm{~m}^{-2} \mathrm{yr}^{-1}$, but with seven periods of dust deposition clearly identifiable for the last 6100 years and several smaller fluctuations prior to that (mainly visible in the elemental data). The main peaks are similar in their timing to the Itrax Ti trend, with three large peaks (dust flux $>1.5 \mathrm{~g} \mathrm{~m}^{-2} \mathrm{yr}^{-1}$ ) located between $5400-5050,2100$ 1450, and 800-620 cal yr BP (Fig. 3). Smaller peaks are 


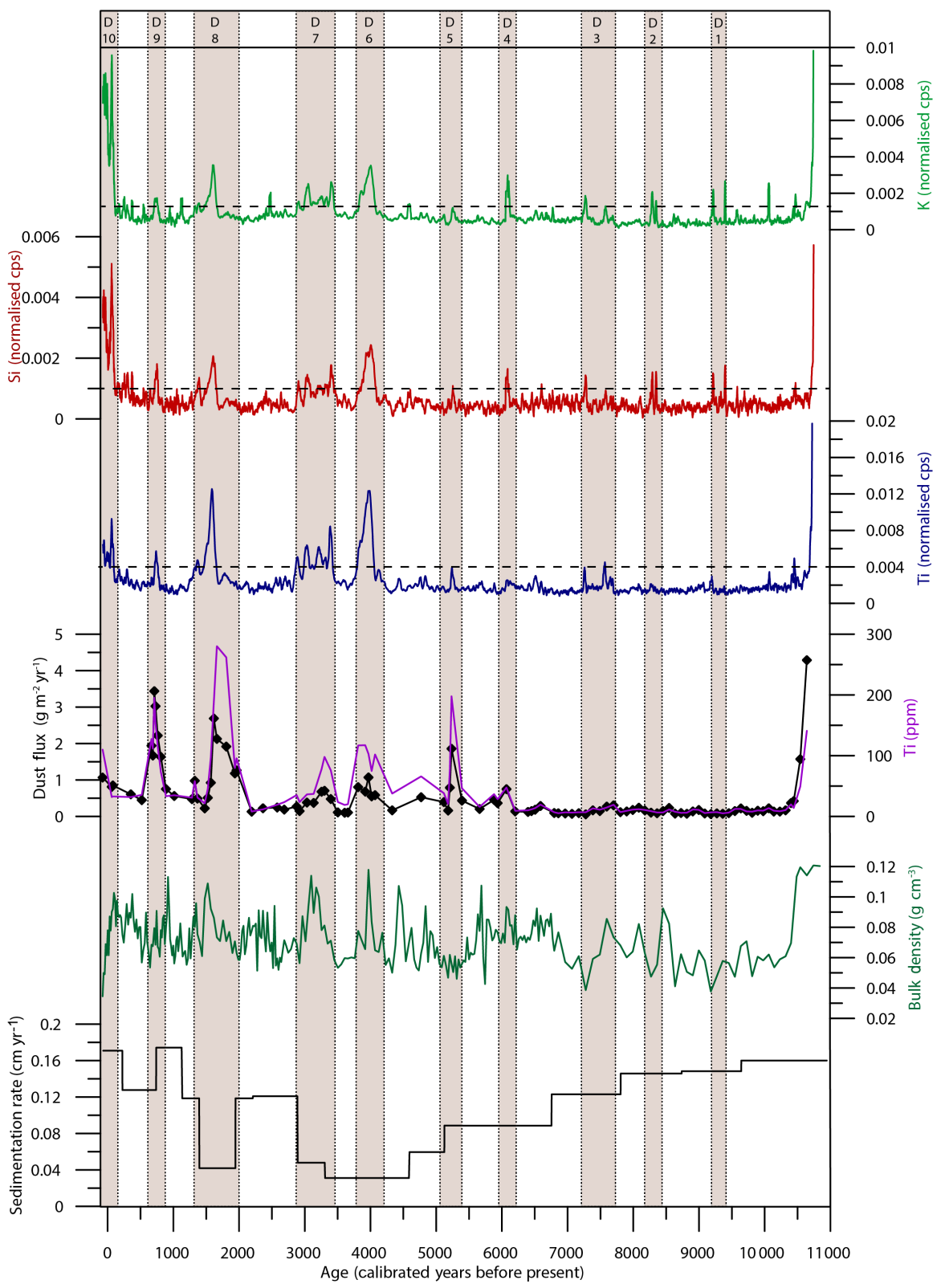

Figure 3. Itrax data of lithogenic element (K, Si, and Ti) concentration throughout the Mohos peat record, with all data smoothed using a nine-point moving average to eliminate noise. Furthermore, dust flux as reconstructed from Ti concentration values (also displayed) and sedimentation rate is presented. Dust events (D0-D10), as identified from increases in at least two of the lithogenic elements under discussion, are highlighted in brown and labelled. Dashed lines on Itrax data indicate the enrichment above which a dust event is denoted.

present (dust flux $0.5-1.5 \mathrm{~g} \mathrm{~m}^{-2} \mathrm{yr}^{-1}$ ) at $6100-6000,4150$ 3770 , and 3500-2850 cal yr BP.

\subsection{Density and loss-on-ignition (LOI)}

Density values are relatively stable throughout the core, with all samples ranging between 0.06 and $0.1 \mathrm{~g} \mathrm{~cm}^{-3}$. This trend is different from the organic matter values, which typically oscillate around $90-100 \%$ over the entire record. The very base of the record is however an exception, de- noting the gradual transition from limnic clays to the peat, reaching organic matter values of $80-90 \%$ between 10800 and 10000 cal yr BP. Very occasional intervals with lower organic matter content (roughly $85 \%$ ) may be observed at $5400,4100-3900,3300-3200,1900-1800$, and 900 800 cal yr BP (Fig. 4). 


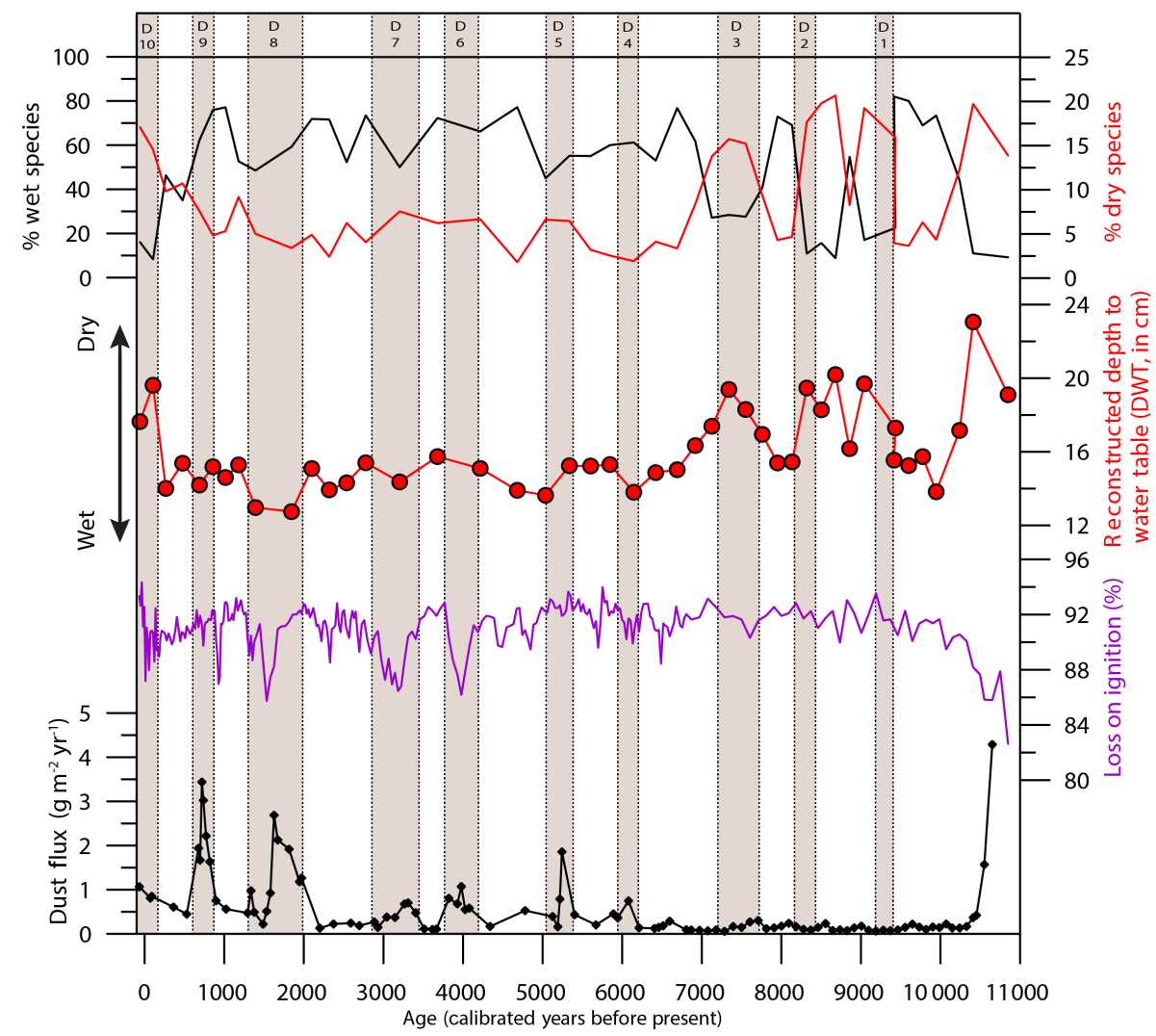

Figure 4. Comparison of Ti-derived dust flux record with wet and dry TA indicator species percentage values, reconstructed depth to water table (DWT), and organic matter (as indicated by loss on ignition). Vertical bars as in Fig. 3.

\subsection{Testate amoeba}

Two methods of clarifying the paleoclimate signal derived through investigating testate amoeba assemblages have been used (Charman et al., 2000; Schnitchen et al., 2006), with both indicating similar hydroclimatic trends. Reconstructions of DWT values indicate three main trends within the record. The first encompasses the time period between 10800 and $7000 \mathrm{cal} \mathrm{yr} \mathrm{BP}$ and is characterised by highly fluctuating values, with four very dry periods (DWT $\sim 20 \mathrm{~cm}$ ) at $10800-10200,9000-8800,8600$ 7600 , and 7400-6600 cal yr BP interspersed by wetter (DWT $15 \mathrm{~cm}$ ) conditions (Fig. 4). After $7000 \mathrm{cal}$ yr BP, values are much more stable, with DWT of $15 \mathrm{~cm}$ until the final zone, the last 100 years, in which DWT rises to $20 \mathrm{~cm}$. These fluctuations are in line with those seen in the wet-dry indicator species.

\subsection{Wavelet analysis}

The wavelet analysis of $\mathrm{K}, \mathrm{Si}$, and $\mathrm{Ti}$ shows significant periodicities between 1000 and 2000 years within the past 6000 years (Fig. 8). Prior to this, there appears to be no major cyclicity in the Itrax data. Within periods that display raised Itrax counts, shorter frequency (50-200 years) cycles are seen. These persist only for the period in which each element is enriched, with such cycles particularly evident within the last 6000 years.

\section{Discussion}

\subsection{Peat ombrotrophy}

The relative intensities of the lithogenic elements analysed via Itrax co-vary throughout the record (Fig. 3), despite their varying post-depositional mobility (Francus et al., 2009; Kylander et al., 2011). For example, the largely immobile Ti shows a very high correlation with that of redox-sensitive $\mathrm{Fe}\left(R^{2}=0.962\right)$ and mobile $\mathrm{K}\left(R^{2}=0.970\right)$. This indicates that the downcore distribution of these elements is mostly unaffected by post-depositional mobilisation via groundwater leaching and/or organic activity as documented in other studies (e.g. Novak et al., 2011; Rothwell et al., 2010). This in turn indicates that the conservative behaviour of such elements in the studied peat. This, alongside the low clastic content (average organic matter of $91 \%$ ), low density, and domination of Sphagnum organic detritus, indicates the ombrotrophic nature of the Mohos bog throughout time and validates the use of this record to reconstruct dust fluxes for the last ca. 10000 years (Fig. 3). 


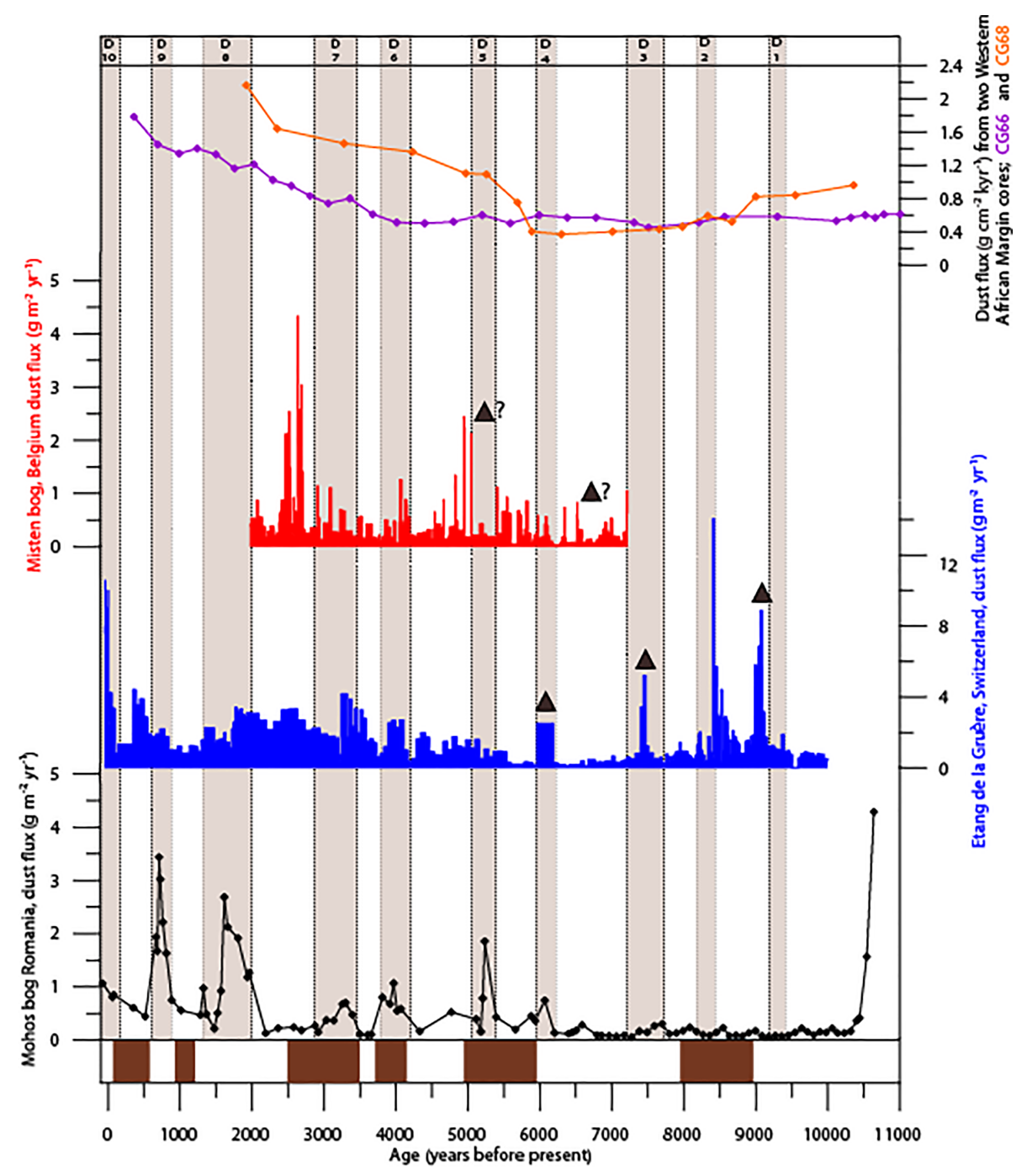

Figure 5. Comparison of dust flux values as reconstructed from the Mohos peat bog with similar records. Two western African dust flux records (GC 68 and 66) from marine cores (McGee et al., 2013) are presented alongside bog-based records from Misten bog in Belgium (Allan et al., 2013) and Etang de la Gruére in Switzerland (Le Roux et al., 2012). Indicated on these records are volcanic events as identified by the authors (brown triangles). These are presented alongside the dust flux record from Mohos (lower panel). Also shown, in brown, are periods of rapid climate change derived from Greenland ice (Mayewski et al., 2004). Vertical bars as in Fig. 3.

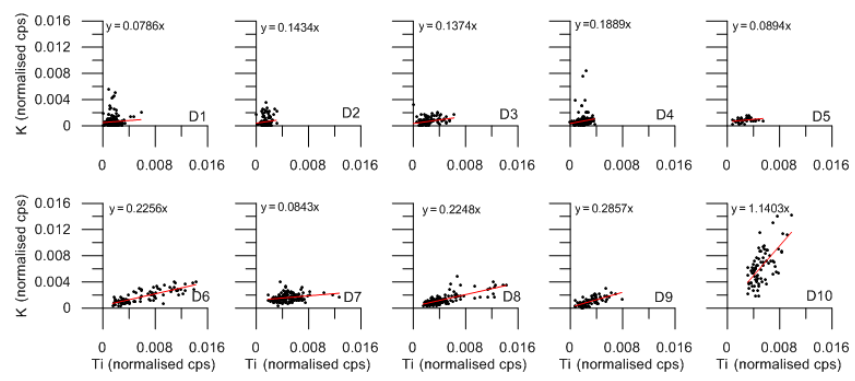

Figure 6. Correlation graphs and gradients of normalised Ti versus normalised $\mathrm{K}$ for each of the dust events (D1-D10).

\subsection{The dust record}

The record of inferred lithogenic (dust) input as indicated by $\mathrm{Ti}, \mathrm{K}$, and/or Si documents 10 well-constrained periods of major and abrupt dust deposition (denoted D0-D10), with further small, short-term fluctuations (Fig. 3). The dust influx onto the Mohos peat was accompanied by decreases in organic matter $(\mathrm{OM})$ as indicated from the LOI profile and higher density values (Fig. 4), particularly over the intervals covered by events D5-D10. The major dust deposition events lasted from a few decades to centuries (Fig. 3).

Firstly, it is noteworthy that five of the identified dust depositional events may be compared to periods of rapid climate change (RCC) as outlined by Mayewski et al. (2004) from the Greenland GISP2 record (Fig. 5). However, de- 


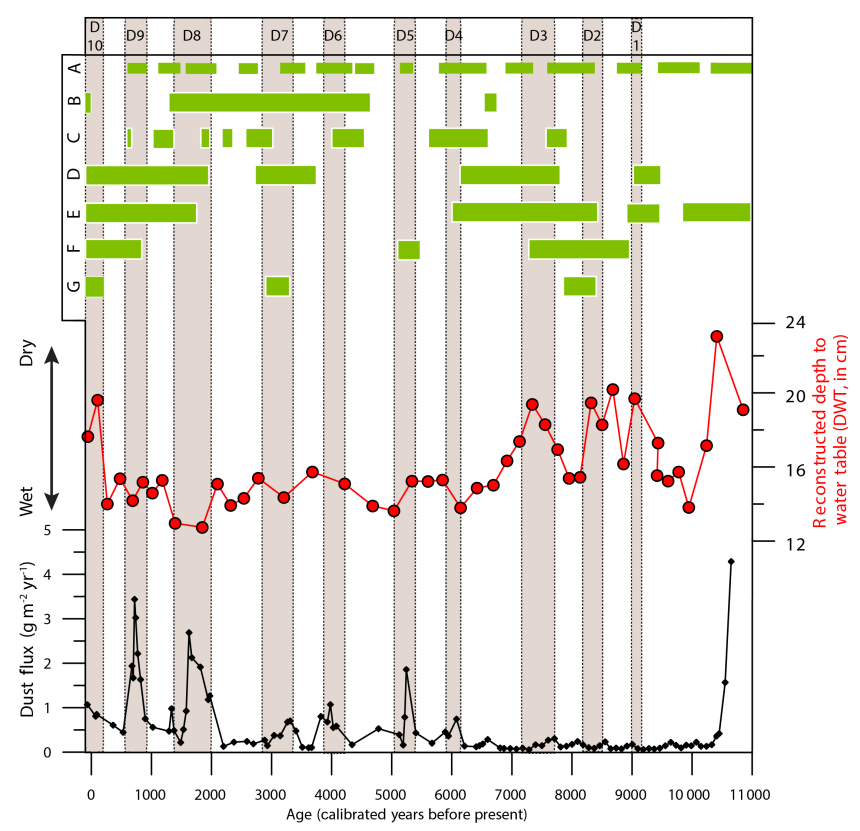

Figure 7. Comparison of dust events and bog wetness as reconstructed from the Mohos record to regional hydroclimate reconstructions. Data presented via green bars is drought, dry, and/or low lake periods from the following publications. A: Magny, 2004; B: Cristea et al., 2013; C: Gałka et al., 2016; D: Magyari et al., 20131; E: Buczkó et al., 2013; F: Magyari et al., 2009; and G: Schnitchen et al., 2006. These are presented alongside the Mohos testate-amoebaderived depth to water table record and Ti-derived dust flux.

spite apparent hemispheric-scale influences, the dust events identified within the Mohos record have little correlation to reconstructed European paleoclimate changes during the Holocene. For example, D8, between 3450 and 2800 cal yr BP, falls within a Europe-wide cold period (Wanner et al., 2011). Such cold-related dust deposition has been previously observed in western Europe. However, within Mohos such a conclusion may not be drawn for the majority of dust events. For example, event D9 (860-650 cal yr BP) occurs during the Medieval Climate Anomaly, a period of generally higher European temperatures (Mann et al., 2009) but also one of intense human impact on the environment through deforestation and agriculture (Arnaud et al., 2016; Kaplan et al., 2009). Furthermore, such events within the Misten record (Allan et al., 2013) were also linked to low humidity, whereas the Mohos TA (Fig. 4) record indicates locally wet conditions. This suggests that dust depositional events in this region are a result of a complex interplay of environmental conditions in the dust source areas rather than simply reflecting locally warm or cold or even wet or dry periods.

In addition to the North Atlantic, the impact of both the Mediterranean and the intertropical convergence zone (ITCZ) atmospheric systems influencing the Mohos dust record are apparent, including major climate changes in
North Africa. D4, for example, occurs within the chronological span of the $5900 \mathrm{cal}$ yr BP event, a major cooling and drying period (Bond et al., 2001; Cremaschi and Zerboni, 2009; Shanahan et al., 2015). Increased dust influx is also recorded around $5300 \mathrm{cal}$ yr BP (D5, Fig. 3), which roughly correlates with the end of the African Humid Period and the onset of Saharan desertification (deMenocal et al., 2000). The lack of dust flux perturbations prior to $6100 \mathrm{yr} \mathrm{BP}$ and their prevalence thereafter at Mohos are consistent with a major shift in the controls of dust production and deposition at this time, a change observed in peat-derived dust records from western Europe (Allan et al., 2013; Le Roux et al., 2012). The desertification of the Sahara around this time was the largest variation in dust production in the Northern Hemisphere (see McGee et al., 2013; deMenocal et al., 2000).

Within our record, this initial dust flux increase was followed by a period of reduced dust loading prior to a rapid, and apparently major (highest dust flux values in the record prior to the most recent 2 millennia), event at 54005000 cal yr BP. Regionally, Saharan dust in Atlantic marine cores strongly increased at this time, with a $140 \%$ rise at roughly 5500 cal yr BP observed on the western Saharan margin (Adkins et al., 2006), with another study indicating a rise by a factor of 5 by $4900 \mathrm{cal}$ yr BP at a selection of similarly located sites (McGee et al., 2013). Furthermore, evidence from marine cores across the Mediterranean indicate decreasing Nile output and increasing dust fluxes into the eastern Mediterranean at this time (Box et al., 2011; Revel et al., 2010). The correlation of these data to the Mohos record appears indicative of the region-wide impact of North African desertification. It is noteworthy, as seen in Fig. 5, that the release of dust from the Sahara correlates well with increasing frequency and intensity of dust fluxes at Mohos after $6000 \mathrm{cal}$ yr BP, with all major (dust flux $>0.5 \mathrm{~g} \mathrm{~m}^{-2} \mathrm{yr}^{-1}$ ) Ti-derived dust flux peaks occurring after this time (Fig. 3). This period is the first indication of the impact the Mediterranean climate and movement of the ITCZ has had on the Carpathian-Balkan region (as simulated by Egerer et al., 2016, and Boos and Korty, 2016). Indeed, intermittent intrusions of Saharan dust over the Carpathian area have been well documented both through direct observations (Labzovskii et al., 2014; Varga et al., 2013) and through provenance studies of past Saharan dust contribution within interglacial soils in the region (Varga et al., 2016).

In addition to Saharan desertification, it is likely that early agriculture in the Carpathian-Balkan region has contributed towards the increase in dust flux values at this time. It is known that advanced agriculture-based societies inhabited the Carpathian area in the mid-Holocene (Carozza et al., 2012), with evidence of farming seen in a number of pollen records (see Schumacher et al., 2016 for a compilation), including in Mohos itself at the end of the Chalcolithic period (Tanţau et al., 2003). Since agriculture and soil erosion may be linked, it is possible that events D4 and D5 could also reflect to some extent dust input related to land disturbance 

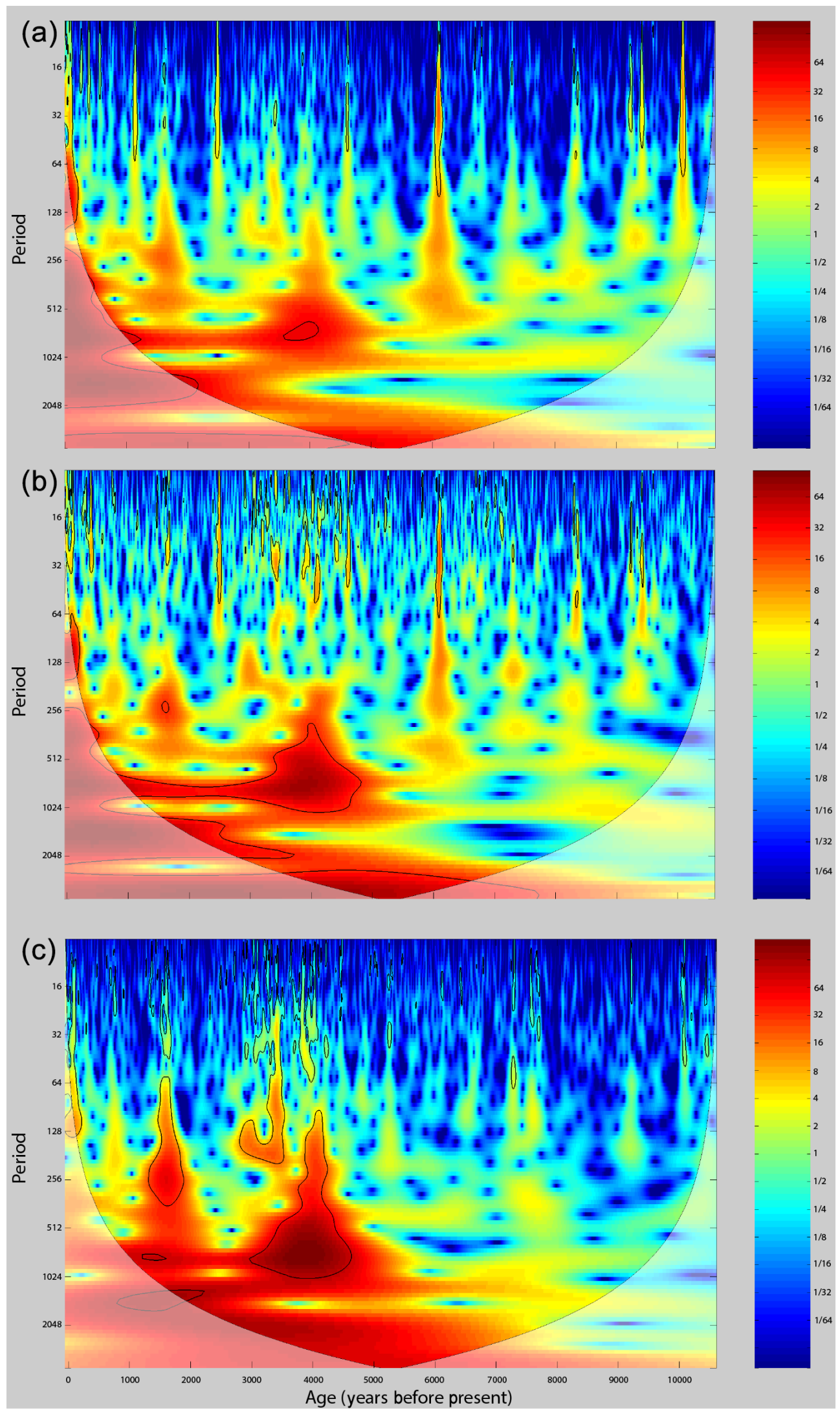

Figure 8. Spectral analysis of Mohos Itrax geochemical data for (a) K, (b) Si, and (c) Ti. Areas outlined in black are significant at the $95 \%$ confidence level. Shaded area indicates the cone of influence, outside of which results may be unreliable. 
by human activities, on a regional scale. However, such evidence for agriculture, particularly in the proximity of Mohos, is limited to a few Plantago and cereal pollen (Tanţau et al., 2003), whilst the majority of pollen studies in Romania at this time indicate no significant agricultural indicators (e.g. Magyari et al., 2010; Schumacher et al., 2016; Tanţau et al., 2014). As such, it seems unlikely that agricultural activity is behind such a large change in the dust deposition record from Mohos.

\subsection{Geochemical evidence for a dust provenance shift at $6100-6000$ cal yr BP?}

To better understand the nature of the shift in dust flux after $6100-6000 \mathrm{cal}$ yr BP, a simple approach to disentangling the geochemical makeup of the reconstructed dust load is discussed below. Figure 6 displays the clustering of the lithogenic elements $\mathrm{Ti}$ and $\mathrm{K}$ (and $\mathrm{Si}$, due to the similarity in the Si and K records) during dust events D1-D10. The data appear to show three main types of dust (and presumably sources): one with high values for both $\mathrm{Ti}$ and $\mathrm{K}$ (Type 1), one with relatively high values for $\mathrm{K}$ (Type 2), and one with relatively high Ti compared to $\mathrm{K}$ (Type 3 ). The values for $\mathrm{Ti}-\mathrm{K}$ correlation, average $\mathrm{Ti}$, and average $\mathrm{K}$ (in normalised cps) are listed in Table 2. Generally, the periods of no enrichment, and low $\mathrm{K}$ and $\mathrm{Ti}$, do not show any correlation, which is indicative of natural background and instrumental detection limits.

Type 1 deposition occurs only in D10 and is characterised by a Ti-K gradient of nearly 1 , indicating similar values for both elements throughout the period and a dust rich in both $\mathrm{K}$ and Ti. Type 2 deposition occurs in several of the dust events, particularly in D1-2, D4-5, and D7 (Fig. 8). The K enrichment that characterises these events is evidenced by the Ti-K gradients $<1$ and low (even negative in the case of D2) correlations between the two elements. Finally, Type 3 events (D3, D6, and D8-9) are characterised by an increased Ti-K gradient, generally around 0.2 . The average Ti values during these events and the Ti-derived dust flux are generally highest in these periods (Table 2). These groupings would indicate similar dust sources within grouped events and may aid in identifying provenance.

Type 2 events typically occur in the older part of the record, except D7 (3400-3000 cal yr BP, Fig. 8). Such events are not visible in the Ti-derived dust flux values, which is indicative of the reduced impact of Ti-bearing dust particles deposited within the corresponding periods. The local rocks consist of K-rich dacites and pyroclastics (Szakács et al., 2015), with relatively low Ti concentrations and enriched in $\mathrm{K}$ (Vinkler et al., 2007). Therefore, the likely source of particulates deposited during these dust events is local or regional, with nearby (or even distal) loess and loess-like deposits as another potential source since loess sediments in south-eastern Europe are generally depleted in $\mathrm{Ti}$ (Buggle et al., 2008). The local nature of such deposition is emphasised by the similarity of the depositional signal to background values, the elemental composition outside of dust events. For all data points not considered to be related to dust (or the minerotrophic lowermost section), the Ti-K regression is low $\left(r^{2}=0.1513\right)$, with a gradient of 0.0863 .

Type 3 events, conversely, appear Ti-enriched (Fig. 6), with contribution from a source away from the low-Ti dust of south-eastern European loess fields. These events typically occur after 6100 cal yr BP (Fig. 3). With the periodic influence of the Mediterranean air masses in the region (Apostol, 2008; Bojariu and Paliu, 2001), Saharan dust must be considered as a potential source area since it appears to play a major role in dust input into Europe today (e.g. Athanasopoulou et al., 2016). Geochemically, Saharan dust is typically Tienriched (Nicolás et al., 2008). In particular, the Bodélé depression, the single largest dust source in the Sahara, exhibits extremely high $\mathrm{Ti} / \mathrm{Al}$ and Ti enrichment (Bristow et al., 2010; Moreno et al., 2006). Since Ti enrichment does not show any regional trends, it is no use for determining exact source areas within the Sahara (Scheuvens et al., 2013), but the presence of Ti-enriched dust appears to reflect a signal of Saharan influence. Consequently, events of Type 3 may be considered to reflect, at least to a large extent, contribution of Saharan dust. Finally, the single Type 1 event may be attributable to a mixing of both local (resulting in high $\mathrm{K}$ ) and distal (resulting in high Ti) sources, which is evidence for Saharan input and local soil erosion and deflation.

Previous work has indicated the input of Saharan dust in eastern Europe, with evidence of such a source seen in Carpathian loess (Újvári et al., 2012; Varga et al., 2013) and soil-forming dust (Varga et al., 2016). Additionally, recent atmospheric satellite imagery has further confirmed the extent of Saharan dust outbreaks and depositional events over central-eastern Europe (Varga et al., 2013). However, the lack of long-term dust reconstructions in the region has so far precluded understanding of changing dust sources over the Holocene.

Previous studies across Europe indicate the complex input of dust from various sources over the mid-to-late Holocene (e.g. Veron et al., 2014), but pertinent to our findings at Mohos, many examples exhibit a major shift in dust sources at roughly $5000-7000 \mathrm{cal} \mathrm{yr} \mathrm{BP.} \mathrm{In} \mathrm{Belgium,} \mathrm{Nd}$ isotopes indicate a local source of dust from the input of European loess prior to and Saharan dust after $6500 \mathrm{cal} \mathrm{yr} \mathrm{BP} \mathrm{(Al-}$ lan et al., 2013). This is echoed by data from Le Roux et al. (2012) that imply a major shift in the Nd isotopic composition at $6000 \mathrm{cal} \mathrm{yr} \mathrm{BP}$, moving from a local to a mixed source, but with clear Saharan overprinting. The transition identified within the Mohos Ti-derived dust record at 6100$6000 \mathrm{cal} \mathrm{yr} \mathrm{BP}$, therefore, appears to echo the appearance of a Saharan dust element within other European bog-based dust reconstructions. However, it appears that input of Saharan dust was not limited to the onset of northern African desertification, as indicated by input of likely Saharan-derived dust within Mohos event D3 already by $7800-7200$ cal yr BP. Fur- 
Table 2. Ti-K correlation $\left(R^{2}\right)$ alongside average cps for $\mathrm{K}$ and $\mathrm{Ti}$ for each of the dust events as identified within the Mohos core.

\begin{tabular}{lrrrrrrrrrr}
\hline Dust Event & D1 & D2 & D3 & D4 & D5 & D6 & D7 & D8 & D9 & D10 \\
\hline Ti-K correlation $\left(R^{2}\right)$ & 0.072 & 0.111 & 0.314 & 0.162 & 0.296 & 0.809 & 0.248 & 0.758 & 0.671 & 0.645 \\
Average Ti (normalised cps) & 0.0015 & 0.0015 & 0.0022 & 0.0018 & 0.0026 & 0.0061 & 0.0048 & 0.0044 & 0.0031 & 0.0052 \\
Average K (normalised cps) & 0.0006 & 0.0006 & 0.0006 & 0.0007 & 0.0009 & 0.0018 & 0.0016 & 0.0013 & 0.0011 & 0.0064 \\
\hline
\end{tabular}

thermore, even after 6100 cal yr BP, local sources still played a significant role, with D7 showing a clear local or regional (e.g. loess-derived) signal.

D10 is interesting in that it appears to indicate even more $\mathrm{K}$-rich dust sources. The D10 values are similar in compositional gradient to the lake sediments deposited prior to the onset of peat formation in the early Holocene (gradient of samples pre- $10500 \mathrm{yr} \mathrm{BP}=0.7429, \mathrm{D} 10=1.0637$ ). Since the surrounding dacites and pyroclastics are K-rich (Vinkler et al., 2007) and the sediment composition prior to peat formation reflects the natural signal of erosion into the lake, it is reasonable to assume that this period is indicative of local slope erosion. This is potentially due to the decline of the local forest and agricultural intensification, identified in the most recent sections of the Mohos pollen record (Tanţau et al., 2003). It is sensible to assume that the local deforestation (visible around the Mohos bog as meadows for hay harvesting) has caused local soil erosion and increased dust production from very proximal sources (Mulitza et al., 2010). This is a clear sign of the persistent human impact on local to regional scales during the early Holocene (Giosan et al., 2012; Schumacher et al., 2016), which is also mirrored in the nearby Lake Sfânta Ana record (Magyari et al., 2009). As indicated by regional studies (e.g. Labzovskii et al., 2014; Varga et al., 2013; Vukmirović et al., 2004), high levels of Ti indicate that Saharan input does not cease through this period but that it is matched by local high-K sources. The apparent higher water table of the Mohos bog as implied by the TA record and the increased $\mathrm{Ti}$ contents rather points towards an increasing Saharan influence rather than a major local dust source.

\subsection{Correlation to other European dust records}

Comparison to similar dust records from peat cores in western Europe (Allan et al., 2013; Le Roux et al., 2012) and Atlantic margin sediments (McGee et al., 2013) reveals some interesting trends visible in all these records (Fig. 5), indicating comparable continent-wide controls on past dust flux. Specifically, the major dust event as seen at 54005000 cal yr BP in Mohos and the subsequent increase in number and intensity of dust events is comparable with an intensification of dust deposition over Europe after $6000 \mathrm{cal}$ yr BP (Le Roux et al., 2012), with concurrent increases in dust flux in the mid-Holocene documented in Belgium (Allan et al., 2013). The authors suggest a cool period as the cause of this dust increase (Wanner et al., 2011). In addition to the reconstructed cool environments in western Europe, this period is characterised by increased dust production in the Sahara (McGee et al., 2013), which is also likely to have played a role in the increasing dust flux over Europe. After $5000 \mathrm{cal}$ yr BP, it appears that Mohos and central-western European records show a more concurrent trend, with comparable dust peaks in the Swiss record (Le Roux et al., 2012) between 4100-3800, 3600-3050, 850-600, and 75 cal yr BP also present in Mohos and a similar dust peak at 32002800 cal yr BP identified in another bog record from Bohemia (Veron et al., 2014).

Despite some similarities between the records, there is also significant variability, highlighting the difference between climatic controls in western and central Europe and those in south-eastern Europe. The disconnection between Mohos and other records is particularly clear for the early Holocene, with a large dust flux peak identified in Switzerland between 9000 and $8400 \mathrm{cal}$ yr BP, and other volcanic-eruption-related dust (see Fig. 5), when there is little evidence of dust input into Mohos. This discrepancy could be indicative of the eastwest (Davis et al., 2003; Mauri et al., 2015; Roberts et al., 2012) and north-south (Magny et al., 2013) hydroclimatic gradients in Europe throughout the Holocene. As other studies indicate, south-eastern Europe was mostly disconnected (in terms of both precipitation and temperature) from the rest of Europe in the early mid-Holocene (Davis et al., 2003; Drăguşin et al., 2014), clearly indicated by the trend in the Mohos Ti-derived dust record. Since the Sahara had not undergone significant desertification by this time, no clear correlation with western records may be made, hinting at a more local source for the earliest five dust events identified within the Mohos record (Fig. 3). In addition, the dust events occurring during the early to mid-Holocene, which are not present in the Ti-derived dust record at Mohos, are more likely related to local fluctuations in moisture availability and $\mathrm{Si}$ and $\mathrm{K}$ rich soil dust.

\subsection{Palaeoecological proxy record}

To further investigate the difference between local and regional palaeoclimate signals within Mohos, and to reconstruct the local hydroclimate conditions throughout the record, we use the fossil assemblages of TA. These data, alongside comparisons to existing Carpathian-Balkan and Mediterranean hydroclimate reconstructions (Fig. 7), may 
be used to further investigate the theory of a distal (most likely Saharan) source for dust after $6100 \mathrm{cal} \mathrm{yr} \mathrm{BP.} \mathrm{The}$ earliest section in the TA record $(10800-6400$ cal yr BP) is characterised by fluctuating dry-wet periods, indicative of large shifts in the local hydroclimatic environment (Fig. 4). The earliest identified dry period (10 800-10 $000 \mathrm{cal} \mathrm{yr} \mathrm{BP})$ is linked to the shift away from a lacustrine to a palustrine environment as a result of local drying. Three subsequent dry periods may be identified in the TA record: $9300-8800,8500$ 8100 , and 7800-7000 cal yr BP, all of which are also identifiable in the geochemical dust record (D1-D3) via peaks in K and Si. Between 10200 and 7450 cal yr BP, dust flux at Mohos was low. Dust events during this time are mainly present in the $\mathrm{K}$ and Si records (Fig. 3) or in OM and density parameters (Fig. 4).

The first period of elevated dust proxies at roughly 10300 cal yr BP (D0) correlates well with the 10200 cal yr BP oscillation (Rasmussen et al., 2007), previously linked to a drop in water levels at nearby Lake Sfânta Ana (Korponai et al., 2011; Magyari et al., 2012, 2014). High Difflugia pulex and Trigonopyxis arcula values during D1 as indicator taxa for dry conditions (Allan et al., 2013; Charman et al., 2000) appear to confirm local drying, observed across much of the Mediterranean (Berger et al., 2016; Buczkó et al., 2013; Magyari et al., 2013; Fig. 7). The D2 and D3 events may also be observed in both the TA record and the geochemical dust record, with D2 attributable to the 8200 cal yr BP event (Bond et al., 2001), a paleoclimatic event already identified in other local hydroclimate reconstructions (Buczkó et al., 2013; Magyari et al., 2013; Schnitchen et al., 2006). The transition to the next wet period at 8000 cal yr BP also mirrors the dust record, with a deeper water table occurring during the dust-free conditions between D2 and D3. This is prior to the bog undergoing dry conditions between 7800 and 7000 cal yr BP, roughly in line with D3, showing drying that has previously been observed in Romania (Gałka et al., 2016; Magyari et al., 2009; Fig. 7). Due to the covariance between geochemical and palaeoecological proxies at this time, and the correlation with other local reconstructions, the early Holocene section of the record indicates a close linkage of local hydroclimate and dust input. These dust events are therefore likely to be the signal of remobilised material (Edri et al., 2016) from proximal or distal sources (including perhaps from loess-derived sediments at the foot of Ciomadul volcano) as the climate locally appears to become more arid.

Between 6600 and 1200 cal yr BP, the TA indicates a shift to prolonged wet conditions, with only minor fluctuations and no clear correlation with the geochemically derived dust record; thus, the dust events appear unrelated to local drying within this time period (Fig. 7). Such wetter conditions also limit local drought-related erosion and may thus be further evidence of distal dust input at this time (Allan et al., 2013). Furthermore, this is indicative of a decoupling of the dust record from local climate reconstructions, with dry phases common throughout the mid- to late Holocene at other Romanian sites (e.g. Magyari et al., 2009; Schnitchen et al., 2006; Fig. 7) and a distal dust source.

In the last millennium, there were two major dust events, with the first, D9, occurring between 850 and 650 cal yr BP. This episode falls within the late Medieval Warm Period and could be related to human activity in the local area, as pollen from the Mohos bog indicates strong evidence for agriculture at roughly the same time (Tanţau et al., 2003). This may be seen in the intensity of the dust deposition at this time (dust flux $>3 \mathrm{~g} \mathrm{~m}^{-2} \mathrm{yr}^{-1}$ ). D10, from $75 \mathrm{cal}$ yr BP to present, is certainly linked to such human influences, with the TA record echoing local studies, which display anthropogenically altered conditions and intensive agriculture (Buczkó et al., 2013; Diaconu et al., 2016; Giosan et al., 2012; Magyari et al., 2009, 2013; Morellón et al., 2016; Schnitchen et al., 2006; Fig. 7). This appears to validate the geochemical approach used earlier, as intensive farming is likely to result in local dust mobilisation, with K-rich dust present at this time and local input potentially erasing some distal signals. This does not preclude Saharan input, however, as the dust is also Ti-rich.

\subsection{Periodicity}

To further understand the nature of the reconstructed dust events, cyclicity within the geochemical record was investigated using wavelet analysis (Fig. 8). The main elements of interest $(\mathrm{Ti}, \mathrm{Si}$, and $\mathrm{K})$ have no apparent cyclicity in the first half of the record (10800-6000 cal yr BP) when there is low spectral power at all periods. In contrast, the last 6000 years display clear centennial- and millennial-scale cycles. A number of other studies have identified cyclicity shifts at this time (Fletcher et al., 2013; Jiménez-Espejo et al., 2014; Morley et al., 2014), related to North Atlantic variability, but so far mainly in western Mediterranean records. From 6000 cal yr BP onwards, the geochemical record at Mohos preserves two main cyclicities: one millennial cycle (at $\sim 1200-2000$ years) and the second at $\sim 600-800$ years (Fig. 8). A 715-775-year cycle has been determined as a harmonic of Bond-event-related dry periods, present in other Northern Hemisphere records (Springer et al., 2008) and in central Africa (Russell et al., 2003). The millennial-scale cycle, in contrast, is within the envelope of a 1750-year cycle observed within the western Mediterranean in pollen (Fletcher et al., 2013) and Saharan dust (Debret et al., 2007; Jiménez-Espejo et al., 2014), which is attributed to changes in North Atlantic circulation.

Within the dust deposition events (Fig. 3), there is an overprinting of high-frequency cyclicity in the Ti record, especially within the last 5000 years (Fig. 8). These are particularly clear at 4200, 3400, and 1800 cal yr BP, but lower-power cyclicities may be seen in most dust deposition events. These are generally 100-200 years in length and only last the extent of the dust outbreak. Cycles with lower than 140-year peri- 
odicities possibly reflect mainly background noise (Turner et al., 2016), but those longer in duration may be indicative of climatically forced fluctuations within drought events affecting the dust source areas. This suggests that the reconstructed dust deposition events based on the Mohos record were not characterised by constant deposition of dust, but by periodic dust pulses. These short cycles could reflect solar forcing, with comparable 200-year cycles observed in humification profiles from peats (Swindles et al., 2012), sediments in the Baltic Sea (Yu, 2003) and Pacific Ocean (Poore et al., 2004), and in North American peatland isotope records (Nichols and Huang, 2012). In many cases, such cycles have been linked to lower solar activity periods, low temperatures, and increased precipitation oscillations, related to the De Vries/Suess 200year cycle (Lüdecke et al., 2015). In the case of Mohos, these fluctuations may have manifested themselves as shifts in dust deposition and could indicate the persistent effect solar dynamics have on all facets of the climate system.

\section{Conclusions}

The first record of Holocene drought and dust input in a bog from eastern Europe documents 10 periods of high dust loading: 9500-9100, 8400-8100, 7720-7250, 6150-5900, 5450-5050, 4130-3770, 3450-2850, 2100-1450, 800-620, and $60 \mathrm{cal}$ yr BP to present.

A major intensification in the number and severity (as indicated by dust flux values) of dust events is observed after $6100 \mathrm{cal} \mathrm{yr} \mathrm{BP}$. The two intervals before and after this shift are indicative of an alteration in major dust controls. For the period prior to $6100 \mathrm{yr} \mathrm{BP}$, dust input is reflective of more local controls, whilst the most recent $6100 \mathrm{yr}$ BP of deposition may be linked to more distal forcings.

The timing of the major shift at $6100 \mathrm{cal} \mathrm{yr} \mathrm{BP}$ is possibly related to the end of the African Humid Period and the establishment of the Sahara Desert, pointing to significantly greater Saharan input within the regional dust loading after this time. This is corroborated by changes in cyclicity attributable to Saharan dust outbreaks and a shift toward Tirich dust (a signal of Saharan rock and sediment) deposited onto the Mohos peat. Our data are the first such indication of the impact Saharan dust has had across eastern Europe, in line with enhanced deposition of dust across the Mediterranean region. A tentative dust provenance analysis based on a simple geochemical approach to disentangle the composition of the dust has been applied to confirm this, with three main types of deposition documented, indicating the interplay between local-regional (mainly loess-derived) and Saharan dust sources over the Holocene.

The most recent dust event, between $75 \mathrm{cal} \mathrm{yr} \mathrm{BP}$ and today is geochemically indicative mainly of local erosion. This may be linked to the increasing human impact through deforestation, agriculture, tourism, and associated soil erosion, indicating a shift in the controls on drought and dust in the region.

\section{The Supplement related to this article is available online at https://doi.org/10.5194/cp-13-897-2017-supplement.}

Author contributions. JL, DV, VE, and US designed the research, interpreted the results, and wrote the paper. DV, MB, and FS performed the fieldwork. JL performed the ICP-OES, testate amoeba, and statistical analysis. VE performed the wavelet analysis. MB and VW performed the Itrax analysis. KH performed the ${ }^{14} \mathrm{C}$ dating. All authors approved the content of the paper.

Competing interests. The authors declare that they have no conflict of interest.

Acknowledgements. We would like to thank Northumbria University for Jack Longman's studentship. This is a contribution to the project PN-II-ID-PCE-2012-4-0530 "Millennial-scale geochemical records of anthropogenic impact and natural climate change in the Romanian Carpathians" and to the Collaborative Research Centre 806 "Our way to Europe" hosted at the University of Cologne, Bonn, and Aachen (subproject B2) granted by the DFG (German Research Foundation).

Edited by: Denis-Didier Rousseau

Reviewed by: Samuel Albani and Nathalie Fagel

\section{References}

Adkins, J., DeMenocal, P., and Eshel, G.: The "African humid period" and the record of marine upwelling from excess 230Th in Ocean Drilling Program Hole 658C, Paleoceanography, 21, 114, https://doi.org/10.1029/2005PA001200, 2006.

Allan, M., Le Roux, G., Piotrowska, N., Beghin, J., Javaux, E., Court-Picon, M., Mattielli, N., Verheyden, S., and Fagel, N.: Mid- and late Holocene dust deposition in western Europe: the Misten peat bog (Hautes Fagnes - Belgium), Clim. Past, 9, 22852298, https://doi.org/10.5194/cp-9-2285-2013, 2013.

Apostol, L.: The Mediterranean cyclones: the role in ensuring water resources and their potential of climatic risk, in the east of Romania, Present Environ. Sustain. Dev., 2, 143-163, 2008.

Arnaud, F., Poulenard, J., Giguet-Covex, C., Wilhelm, B., Révillon, S., Jenny, J.-P., Revel, M., Enters, D., Bajard, M., Fouinat, L., Doyen, E., Simonneau, A., Pignol, C., Chapron, E., Vannière, B., and Sabatier, P.: Erosion under climate and human pressures: An alpine lake sediment perspective, Quat. Sci. Rev., 152, 1-18, https://doi.org/10.1016/j.quascirev.2016.09.018, 2016.

Athanasopoulou, E., Protonotariou, A., Papangelis, G., Tombrou, M., Mihalopoulos, N., and Gerasopoulos, E.: Long-range transport of Saharan dust and chemical transformations over the Eastern Mediterranean, Atmos. Environ., 140, 592-604, https://doi.org/10.1016/j.atmosenv.2016.06.041, 2016. 
Berger, J.-F., Lespez, L., Kuzucuoglu, C., Glais, A., Hourani, F., Barra, A., and Guilaine, J.: Interactions between climate change and human activities during the early to mid-Holocene in the eastern Mediterranean basins, Clim. Past, 12, 1847-1877, https://doi.org/10.5194/cp-12-1847-2016, 2016.

Blaauw, M. and Christen, J. A.: Flexible paleoclimate age-depth models using an autoregressive gamma process, Bayesian Anal., 6, 457-474, https://doi.org/10.1214/ba/1339616472, 2011.

Bojariu, R. and Giorgi, F.: The North Atlantic Oscillation signal in a regional climate simulation for the European region, Tellus, 57A, 641-653, https://doi.org/10.1111/j.16000870.2005.00122.x, 2005.

Bojariu, R. and Paliu, D.-M.: North Atlantic Oscillation Projection on Romanian Climate Fluctuations in the Cold Season, in Detecting and Modelling Regional Climate Change and Associated Impacts, edited by: India, M. B. and Bonillo, D. L., 345-356, Springer Berlin Heidelberg, Berlin Heidelburg, 2001.

Bond, G., Kromer, B., Beer, J., Muscheler, R., Evans, M. N., Showers, W., Hoffmann, S., Lotti-Bond, R., Hajdas, I., and Bonani, G.: Persistent solar influence on North Atlantic climate during the Holocene, Science, 294, 2130-2136, https://doi.org/10.1126/science.1065680, 2001.

Boos, W. R. and Korty, R. L.: Regional energy budget control of the intertropical convergence zone and application to mid-Holocene rainfall, Nat. Geosci., 9, 892-897, doi:10.1038/ngeo2833, 2016.

Booth, R. K., Jackson, S. T., Forman, S. L., Kutzbach, J. E., Bettis, E. a., Kreig, J., and Wright, D. K.: A severe centennialscale drought in midcontinental North America 4200 years ago and apparent global linkages, The Holocene, 15, 321-328, https://doi.org/10.1191/0959683605hl825ft, 2005.

Booth, R. K., Lamentowicz, M., and Charman, D. J.: Preparation and analysis of testate amoebae in peatland palaeoenvironmental studies, Mires Peat, 7, 1-7, 2010.

Box, M. R., Krom, M. D., Cliff, R. A., Bar-Matthews, M., Almogi-Labin, A., Ayalon, A., and Paterne, M.: Response of the Nile and its catchment to millennial-scale climatic change since the LGM from $\mathrm{Sr}$ isotopes and major elements of East Mediterranean sediments, Quat. Sci. Rev., 30, 431-442, https://doi.org/10.1016/j.quascirev.2010.12.005, 2011.

Bristow, C. S., Hudson-Edwards, K. A., and Chappell, A.: Fertilizing the Amazon and equatorial Atlantic with West African dust, Geophys. Res. Lett., 37, L14807, https://doi.org/10.1029/2010GL043486, 2010.

Brooks, N.: Cultural responses to aridity in the Middle Holocene and increased social complexity, Quat. Int., 151, 29-49, https://doi.org/10.1016/j.quaint.2006.01.013, 2006.

Buczkó, K., Magyari, E. K., Braun, M., and Bálint, M.: Diatominferred lateglacial and Holocene climatic variability in the South Carpathian Mountains (Romania), Quat. Int., 293, 123-135, https://doi.org/10.1016/j.quaint.2012.04.042, 2013.

Buggle, B., Glaser, B., Zöller, L., Hambach, U., Marković, S., Glaser, I., and Gerasimenko, N.: Geochemical characterization and origin of Southeastern and Eastern European loesses (Serbia, Romania, Ukraine), Quat. Sci. Rev., 27, 1058-1075, https://doi.org/10.1016/j.quascirev.2008.01.018, 2008.

Buggle, B., Hambach, U., Glaser, B., Gerasimenko, N., Marković, S., Glaser, I., and Zöller, L.: Stratigraphy, and spatial and temporal paleoclimatic trends in Southeastern/Eastern Eu- ropean loess-paleosol sequences, Quat. Int., 196, 86-106, https://doi.org/10.1016/j.quaint.2008.07.013, 2009.

Carozza, J.-M., Micu, C., Mihail, F., and Carozza, L.: Landscape change and archaeological settlements in the lower Danube valley and delta from early Neolithic to Chalcolithic time: A review, Quat. Int., 261, 21-31, https://doi.org/10.1016/j.quaint.2010.07.017, 2012.

Chambers, F. M., Booth, R. K., De Vleeschouwer, F., Lamentowicz, M., Le Roux, G., Mauquoy, D., Nichols, J. E., and van Geel, B.: Development and refinement of proxyclimate indicators from peats, Quat. Int., 268, 21-33, https://doi.org/10.1016/j.quaint.2011.04.039, 2012.

Charman, D. J., Hendon, D., and Woodland, W.: The identification of testate amoebae (Protozoa: Rhizopoda) in peats, QRA Techni., Quaternary Research Association, London, 147 pp., 2000.

Cremaschi, M. and Zerboni, A.: Early to Middle Holocene landscape exploitation in a drying environment: Two case studies compared from the central Sahara (SW Fezzan, Libya), C. R. Geosci., 341, 689-702, https://doi.org/10.1016/j.crte.2009.05.001, 2009.

Cristea, G., Cuna, S. M., Farcas, S., Tantau, I., Dordai, E., and Magdas, D. A.: Carbon isotope composition as indicator for climatic changes during the middle and late Holocene in a peat bog from Maramures Mountains (Romania), The Holocene, 24, 1523, https://doi.org/10.1177/0959683613512166, 2013.

Cristea, V.: Fitosociologie şi vegetaţia României, Babes-Bolyai University Press, Cluj Napoca, 314 pp., 1993.

Croudace, I. W., Rindby, A., and Rothwell, R. G.: ITRAX: description and evaluation of a new multi-function $\mathrm{X}$ ray core scanner, Geol. Soc. London, 267, 51-63, https://doi.org/10.1144/GSL.SP.2006.267.01.04, 2006.

Davis, B. A. S., Brewer, S., Stevenson, A. C., and Guiot, J.: The temperature of Europe during the Holocene reconstructed from pollen data, Quat. Sci. Rev., 22, 1701-1716, https://doi.org/10.1016/S0277-3791(03)00173-2, 2003.

Debret, M., Bout-Roumazeilles, V., Grousset, F., Desmet, M., McManus, J. F., Massei, N., Sebag, D., Petit, J.-R., Copard, Y., and Trentesaux, A.: The origin of the 1500-year climate cycles in Holocene North-Atlantic records, Clim. Past, 3, 569-575, https://doi.org/10.5194/cp-3-569-2007, 2007.

deMenocal, P., Ortiz, J., Guilderson, T., Adkins, J., Sarnthein, M., Baker, L., and Yarusinsky, M.: Abrupt onset and termination of the African Humid Period: Rapid climate responses to gradual insolation forcing, Quat. Sci. Rev., 19, 347-361, 2000.

deMenocal, P. B.: Cultural responses to climate change during the late Holocene, Science, 292, 667-673, https://doi.org/10.1126/science.1059287, 2001.

Diaconu, A.-C., Grindean, R., Panait, A., and Tanţău, I.: Late Holocene palaeohydrological changes in a Sphagnum peat bog from NW Romania based on testate amoebae, Stud. UBB Geol., 60, 21-28, https://doi.org/10.5038/1937-8602.60.1.1285, 2016.

Drăguşin, V., Staubwasser, M., Hoffmann, D. L., Ersek, V., Onac, B. P., and Veres, D.: Constraining Holocene hydrological changes in the Carpathian-Balkan region using speleothem $\delta^{18} \mathrm{O}$ and pollen-based temperature reconstructions, Clim. Past, 10, 13631380, https://doi.org/10.5194/cp-10-1363-2014, 2014.

Edri, A., Dody, A., Tanner, S., Swet, N., and Katra, I.: Variations in dust-related $\mathrm{PM}_{10}$ emission from an arid land due to surface 
composition and topsoil disturbance, Arab. J. Geosci., 9, 607, https://doi.org/10.1007/s12517-016-2651-z, 2016.

Egerer, S., Claussen, M., Reick, C., and Stanelle, T.: The link between marine sediment records and changes in Holocene Saharan landscape: simulating the dust cycle, Clim. Past, 12, 1009-1027, https://doi.org/10.5194/cp-12-1009-2016, 2016.

Feurdean, A., Klotz, S., Mosbrugger, V., and Wohlfarth, B.: Pollenbased quantitative reconstructions of Holocene climate variability in NW Romania, Palaeogeogr. Palaeoclimatol. Palaeoecol., 260, 494-504, https://doi.org/10.1016/j.palaeo.2007.12.014, 2008.

Feurdean, A., Tamaş, T., Tanţau, I., and Farcaş, S.: Elevational variation in regional vegetation responses to late-glacial climate changes in the Carpathians, J. Biogeogr., 39, 258-271, https://doi.org/10.1111/j.1365-2699.2011.02605.x, 2012.

Feurdean, A., Galka, M., Kuske, E., Tantau, I., Lamentowicz, M., Florescu, G., Liakka, J., Hutchinson, S. M., Mulch, A., and Hickler, T.: Last Millennium hydroclimate variability in Central-Eastern Europe (Northern Carpathians, Romania), The Holocene, 25, 1179-1192, https://doi.org/10.1177/0959683615580197, 2015.

Fletcher, W. J., Debret, M., and Goni, M. F. S.: Mid-Holocene emergence of a low-frequency millennial oscillation in western Mediterranean climate: Implications for past dynamics of the North Atlantic atmospheric westerlies, The Holocene, 23, 153166, https://doi.org/10.1177/0959683612460783, 2013.

Francus, P., Lamb, H., Nakagawa, T., Marshall, M., Brown, E., and Members, S. P.: The potential of high-resolution X-ray fluorescence core scanning?: Applications in paleolimnology, PAGES news, 17, 93-95, 2009.

Gałka, M., Tanţău, I., Ersek, V., and Feurdean, A.: A 9000 year record of cyclic vegetation changes identified in a montane peatland deposit located in the Eastern Carpathians (CentralEastern Europe): Autogenic succession or regional climatic influences?, Palaeogeogr. Palaeoclimatol. Palaeoecol., 449, 52-61, https://doi.org/10.1016/j.palaeo.2016.02.007, 2016.

Giosan, L., Coolen, M. J. L., Kaplan, J. O., Constantinescu, S., Filip, F., Filipova-Marinova, M., Kettner, A. J., and Thom, N.: Early Anthropogenic Transformation of the Danube-Black Sea System, Sci. Rep., 2, 1-6, https://doi.org/10.1038/srep00582, 2012.

Goudie, A. S. and Middleton, N. J.: Desert Dust in the Global System, Springer Berlin Heidelberg, Berlin \& Heidelberg, 288 pp., 2006.

Grinsted, A., Moore, J. C., and Jevrejeva, S.: Application of the cross wavelet transform and wavelet coherence to geophysical time series, Nonlin. Processes Geophys., 11, 561-566, https://doi.org/10.5194/npg-11-561-2004, 2004.

Grousset, F. E. and Biscaye, P. E.: Tracing dust sources and transport patterns using $\mathrm{Sr}, \mathrm{Nd}$ and $\mathrm{Pb}$ isotopes, Chem. Geol., 222, 149-167, https://doi.org/10.1016/j.chemgeo.2005.05.006, 2005.

Grousset, F. E., Ginoux, P., Bory, A., and Biscaye, P. E.: Case study of a Chinese dust plume reaching the French Alps, Geophys. Res. Lett., 30, 1277, https://doi.org/10.1029/2002GL016833, 2003.

Haliuc, A., Veres, D., Brauer, A., Hubay, K., Hutchinson, S. M., Begy, R., and Braun, M.: Palaeohydrological changes during the mid and late Holocene in the Carpathian area, central-eastern Europe, Global Planet. Chang., 152, 99-114, https://doi.org/10.1016/j.gloplacha.2017.02.010, 2017.
Harangi, S., Molnar, M., Vinkler, A. P., Kiss, B., Jull, A. J. T., and Leonard, A. G.: Radiocarbon Dating of the Last Volcanic Eruptions of Ciomadul Volcano, Southeast Carpathians, Eastern-Central Europe, Radiocarbon, 52, 1498-1507, https://doi.org/10.2458/azu_js_rc.52.3648, 2010.

Heiri, O., Lotter, A. F., and Lemcke, G.: Loss on ignition as a method for estimating organic and carbonate content in sediments: Reproducibility and comparability of results, J. Paleolimnol., 25, 101-110, https://doi.org/10.1023/A:1008119611481, 2001.

Jickells, T. D., An, Z. S., Andersen, K. K., Baker, A. R., Bergametti, G., Brooks, N., Cao, J. J., Boyd, P. W., Duce, R. A., Hunter, K. A., Kawahata, H., Kubilay, N., laRoche, J., Liss, P. S., Mahowald, N., Prospero, J. M., Ridgwell, A. J., Tegen, I., and Torres, R.: Global Iron Connections Between Desert Dust, Ocean Biogeochemistry, and Climate, Science, 308, 6771, https://doi.org/10.1126/science.1105959, 2005.

Jiménez-Espejo, F. J., García-Alix, A., Jiménez-Moreno, G., Rodrigo-Gámiz, M., Anderson, R. S., Rodríguez-Tovar, F. J., Martínez-Ruiz, F., Giralt, S., Delgado Huertas, A., and Pardo-Igúzquiza, E.: Saharan aeolian input and effective humidity variations over western Europe during the Holocene from a high altitude record, Chem. Geol., 374, 1-12, https://doi.org/10.1016/j.chemgeo.2014.03.001, 2014.

Kaplan, J. O., Krumhardt, K. M., and Zimmermann, N.: The prehistoric and preindustrial deforestation of Europe, Quat. Sci. Rev., 28, 3016-3034, https://doi.org/10.1016/j.quascirev.2009.09.028, 2009.

Karátson, D., Wulf, S., Veres, D., Magyari, E. K., Gertisser, R., Timar-Gabor, A., Novothny, Telbisz, T., Szalai, Z., Anechitei-Deacu, V., Appelt, O., Bormann, M., Jánosi, C., Hubay, K., and Schäbitz, F.: The latest explosive eruptions of Ciomadul (Csomád) volcano, East Carpathians - A tephrostratigraphic approach for the 51-29ka BP time interval, J. Volcanol. Geotherm. Res., 319, 29-51, https://doi.org/10.1016/j.jvolgeores.2016.03.005, 2016.

Kok, J. F., Mahowald, N. M., Fratini, G., Gillies, J. A., Ishizuka, M., Leys, J. F., Mikami, M., Park, M.-S., Park, S.-U., Van Pelt, R. S., and Zobeck, T. M.: An improved dust emission model - Part 1: Model description and comparison against measurements, Atmos. Chem. Phys., 14, 13023-13041, https://doi.org/10.5194/acp-14-13023-2014, 2014.

Korcz, M., Fudała, J., and Kliś, C.: Estimation of wind blown dust emissions in Europe and its vicinity, Atmos. Environ., 43, 14101420, https://doi.org/10.1016/j.atmosenv.2008.05.027, 2009.

Korponai, J., Magyari, E. K., Buczkó, K., Iepure, S., Namiotko, T., Czakó, D., Kövér, C., and Braun, M.: Cladocera response to Late Glacial to Early Holocene climate change in a South Carpathian mountain lake, Hydrobiologia, 676, 223-235, https://doi.org/10.1007/s10750-011-0881-3, 2011.

Krachler, M., Mohl, C., Emons, H., and Shotyk, W.: Influence of digestion procedures on the determination of rare earth elements in peat and plant samples by USN-ICP-MS, J. Anal. At. Spectrom., 17, 844-851, https://doi.org/10.1039/b200780k, 2002.

Kristó, A.: A Csomád hegycsoport, A Szent-Anna tó természetvédelmi területe (The Nature Reserve of Lake Saint Ana), Kristó András emlékére (In Rememb. András Kristó), Balat. Akadémia Könyvek, 13, 38-45, 1995. 
Kylander, M. E., Ampel, L., Wohlfarth, B., and Veres, D.: High-resolution X-ray fluorescence core scanning analysis of Les Echets (France) sedimentary sequence: new insights from chemical proxies, J. Quat. Sci., 26, 109-117, https://doi.org/10.1002/jqs.1438, 2011.

Kylander, M. E., Bindler, R., Cortizas, A. M., Gallagher, K., Mörth, C. M., and Rauch, S.: A novel geochemical approach to paleorecords of dust deposition and effective humidity: 8500 years of peat accumulation at Store Mosse (the "Great Bog"), Sweden, Quat. Sci. Rev., 69, 69-82, https://doi.org/10.1016/j.quascirev.2013.02.010, 2013a.

Kylander, M. E., Klaminder, J., Wohlfarth, B., and Löwemark, L.: Geochemical responses to paleoclimatic changes in southern Sweden since the late glacial: the Hässeldala Port lake sediment record, J. Paleolimnol., 50, 57-70, https://doi.org/10.1007/s10933-013-9704-z, 2013b.

Kylander, M. E., Martínez-Cortizas, A., Bindler, R., Greenwood, S. L., Mörth, C.-M., and Rauch, S.: Potentials and problems of building detailed dust records using peat archives: An example from Store Mosse (the "Great Bog"), Sweden, Geochim. Cosmochim. Acta, 190, 156-174, https://doi.org/10.1016/j.gca.2016.06.028, 2016.

Labzovskii, L., Toanca, F., and Nicolae, D.: Determination of Saharan dust properties over Bucharest, Romania. Part 2: Study cases analysis, Rom. J. Phys., 59, 1097-1108, 2014.

Lamentowicz, M., Cedro, A., Gałka, M., Goslar, T., MiotkSzpiganowicz, G., Mitchell, E. A. D., and Pawlyta, J.: Last millennium palaeoenvironmental changes from a Baltic bog (Poland) inferred from stable isotopes, pollen, plant macrofossils and testate amoebae, Palaeogeogr. Palaeoclimatol. Palaeoecol., 265, 93-106, https://doi.org/10.1016/j.palaeo.2008.04.023, 2008.

Le Roux, G., Fagel, N., De Vleeschouwer, F., Krachler, M., Debaille, V., Stille, P., Mattielli, N., van der Knaap, W. O., van Leeuwen, J. F. N., and Shotyk, W.: Volcano- and climatedriven changes in atmospheric dust sources and fluxes since the Late Glacial in Central Europe, Geology, 40, 335-338, https://doi.org/10.1130/g32586.1, 2012.

Longman, J., Ersek, V., Veres, D., and Salzmann, U.: Detrital events and hydroclimate variability in the Romanian Carpathians during the Mid-to-Late Holocene, Quat. Sci. Rev., 167, 78-95, https://doi.org/10.1016/j.quascirev.2017.04.029, 2017.

Lüdecke, H.-J., Weiss, C. O., and Hempelmann, A.: Paleoclimate forcing by the solar De Vries/Suess cycle, Clim. Past Discuss., 11, 279-305, https://doi.org/10.5194/cpd-11-279-2015, 2015.

Magny, M.: Holocene climate variability as reflected by midEuropean lake-level fluctuations and its probable impact on prehistoric human settlements, Quat. Int., 113, 65-79, https://doi.org/10.1016/S1040-6182(03)00080-6, 2004.

Magny, M., Combourieu-Nebout, N., de Beaulieu, J. L., BoutRoumazeilles, V., Colombaroli, D., Desprat, S., Francke, A., Joannin, S., Ortu, E., Peyron, O., Revel, M., Sadori, L., Siani, G., Sicre, M. A., Samartin, S., Simonneau, A., Tinner, W., Vanniére, B., Wagner, B., Zanchetta, G., Anselmetti, F., Brugiapaglia, E., Chapron, E., Debret, M., Desmet, M., Didier, J., Essallami, L., Galop, D., Gilli, A., Haas, J. N., Kallel, N., Millet, L., Stock, A., Turon, J. L., and Wirth, S.: North-south palaeohydrological contrasts in the central Mediterranean during the Holocene: ten- tative synthesis and working hypotheses, Clim. Past, 9, 2043 2071, https://doi.org/10.5194/cp-9-2043-2013, 2013.

Magyari, E., Buczkó, K., Jakab, G., Braun, M., Pál, Z., Karátson, D., and Pap, I.: Palaeolimnology of the last crater lake in the Eastern Carpathian Mountains: a multiproxy study of Holocene hydrological changes, Hydrobiologia, 631, 29-63, https://doi.org/10.1007/s10750-009-9801-1, 2009.

Magyari, E. K., Chapman, J. C., Passmore, D. G., Allen, J. R. M., Huntley, J. P., and Huntley, B.: Holocene persistence of wooded steppe in the Great Hungarian Plain, J. Biogeogr., 37, 915-935, https://doi.org/10.1111/j.1365-2699.2009.02261.x, 2010.

Magyari, E. K., Jakab, G., Bálint, M., Kern, Z., Buczkó, K., and Braun, M.: Rapid vegetation response to Lateglacial and early Holocene climatic fluctuation in the South Carpathian Mountains (Romania), Quat. Sci. Rev., 35, 116-130, https://doi.org/10.1016/j.quascirev.2012.01.006, 2012.

Magyari, E. K., Demény, A., Buczkó, K., Kern, Z., Vennemann, T., Fórizs, I., Vincze, I., Braun, M., Kovács, J. I., Udvardi, B., and Veres, D.: A 13,600-year diatom oxygen isotope record from the South Carpathians (Romania): Reflection of winter conditions and possible links with North Atlantic circulation changes, Quat. Int., 293, 136-149, https://doi.org/10.1016/j.quaint.2012.05.042, 2013.

Magyari, E. K., Veres, D., Wennrich, V., Wagner, B., Braun, M., Jakab, G., Karátson, D., Pál, Z., Ferenczy, G., St-Onge, G., Rethemeyer, J., Francois, J.-P., von Reumont, F., and Schäbitz, F.: Vegetation and environmental responses to climate forcing during the Last Glacial Maximum and deglaciation in the East Carpathians: attenuated response to maximum cooling and increased biomass burning, Quat. Sci. Rev., 106, 278-298, https://doi.org/10.1016/j.quascirev.2014.09.015, 2014.

Mahowald, N. M., Kloster, S., Engelstaedter, S., Moore, J. K., Mukhopadhyay, S., Mcconnell, J. R., Albani, S., Doney, S. C., Bhattacharya, A., Curran, M. A. J., Flanner, M. G., Hoffman, F. M., Lawrence, D. M., Lindsay, K., Mayewski, P. A., Neff, J., Rothenberg, D., Thomas, E., Thornton, P. E., and Zender, C. S.: Observed 20th century desert dust variability: impact on climate and biogeochemistry, Atmos. Chem. Phys., 10, 10875-10893, https://doi.org/10.5194/acp-10-10875-2010, 2010.

Mann, M. E., Zhang, Z., Rutherford, S., Bradley, R. S., Hughes, M. K., Shindell, D., Ammann, C., Faluvegi, G., and Ni, F.: Global Signatures and Dynamical Origins of the Little Ice Age and Medieval Climate Anomaly, Science, 326, 1256-1260, https://doi.org/10.1126/science.1177303, 2009.

Marković, S. B., Stevens, T., Kukla, G. J., Hambach, U., Fitzsimmons, K. E., Gibbard, P., Buggle, B., Zech, M., Guo, Z., Hao, Q., Wu, H., O’Hara Dhand, K., Smalley, I. J., Újvári, G., Sümegi, P., Timar-Gabor, A., Veres, D., Sirocko, F., Vasiljević, D. A., Jary, Z., Svensson, A., Jović, V., Lehmkuhl, F., Kovács, J., and Svirčev, Z.: Danube loess stratigraphy - Towards a panEuropean loess stratigraphic model, Earth-Sci. Rev., 148, 228258, https://doi.org/10.1016/j.earscirev.2015.06.005, 2015.

Marx, S. K., McGowan, H. A., and Kamber, B. S.: Long-range dust transport from eastern Australia: A proxy for Holocene aridity and ENSO-type climate variability, Earth Planet. Sci. Lett., 282, 167-177, https://doi.org/10.1016/j.eps1.2009.03.013, 2009.

Marx, S. K., Kamber, B. S., McGowan, H. A., and Zawadzki, A.: Atmospheric pollutants in alpine peat bogs record a detailed chronology of industrial and agricultural development 
on the Australian continent, Environ. Pollut., 158, 1615-1628, https://doi.org/10.1016/j.envpol.2009.12.009, 2010.

Mauri, A., Davis, B. A. S., Collins, P. M., and Kaplan, J. O.: The climate of Europe during the Holocene: a gridded pollen-based reconstruction and its multi-proxy evaluation, Quat. Sci. Rev., 112, 109-127, https://doi.org/10.1016/j.quascirev.2015.01.013, 2015.

Mayewski, P. A., Rohling, E., Curtstager, J., Karlén, W., Maasch, K., Davidmeeker, L., Meyerson, E., Gasse, F., Vankreveld, S., and Holmgren, K.: Holocene climate variability, Quat. Res., 62, 243-255, https://doi.org/10.1016/j.yqres.2004.07.001, 2004

McGee, D., DeMenocal, P. B., Winckler, G., Stuut, J. B. W., and Bradtmiller, L. I.: The magnitude, timing and abruptness of changes in North African dust deposition over the last 20,000 yr, Earth Planet. Sci. Lett., 371-372, 163-176, https://doi.org/10.1016/j.epsl.2013.03.054, 2013.

Miao, X., Mason, J. A., Swinehart, J. B., Loope, D. B., Hanson, P. R., Goble, R. J., and Liu, X.: A 10000 year record of dune activity, dust storms, and severe drought in the central Great Plains, Geology, 35, 119, https://doi.org/10.1130/G23133A.1, 2007.

Molnár, M., Rinyu, L., Veres, M., Seiler, M., Wacker, L., and Synal, H.-A.: EnvironMICADAS?: a mini ${ }^{14} \mathrm{C}$ AMS with enhanced gas ion source, Radiocarbon, 55, 338-344, https://doi.org/10.2458/azu_js_rc.55.16331, 2013.

Morellón, M., Anselmetti, F. S., Ariztegui, D., Brushulli, B., Sinopoli, G., Wagner, B., Sadori, L., Gilli, A., and Pambuku, A.: Human-climate interactions in the central Mediterranean region during the last millennia: The laminated record of Lake Butrint (Albania), Quat. Sci. Rev., 136, 134-152, https://doi.org/10.1016/j.quascirev.2015.10.043, 2016.

Moreno, T., Querol, X., Castillo, S., Alastuey, A., Cuevas, E., Herrmann, L., Mounkaila, M., Elvira, J., and Gibbons, W.: Geochemical variations in aeolian mineral particles from the Sahara-Sahel Dust Corridor, Chemosphere, 65, 261-270, https://doi.org/10.1016/j.chemosphere.2006.02.052, 2006.

Morley, A., Rosenthal, Y., and DeMenocal, P.: Oceanatmosphere climate shift during the mid-to-late Holocene transition, Earth Planet. Sci. Lett., 388, 18-26, https://doi.org/10.1016/j.epsl.2013.11.039, 2014.

Morris, P. J., Baird, A. J., Young, D. M., and Swindles, G. T.: Untangling climate signals from autogenic changes in long-term peatland development, Geophys. Res. Lett., 42, 10788-10797, https://doi.org/10.1002/2015GL066824, 2015.

Mulitza, S., Heslop, D., Pittauerova, D., Fischer, H. W., Meyer, I., Stuut, J.-B., Zabel, M., Mollenhauer, G., Collins, J. A., Kuhnert, H., and Schulz, M.: Increase in African dust flux at the onset of commercial agriculture in the Sahel region, Nature, 466, 226228, https://doi.org/10.1038/nature09213, 2010.

Nichols, J. E. and Huang, Y.: Hydroclimate of the northeastern United States is highly sensitive to solar forcing, Geophys. Res. Lett., 39, L04707, https://doi.org/10.1029/2011GL050720, 2012.

Nicolás, J., Chiari, M., Crespo, J., Orellana, I. G., Lucarelli, F., Nava, S., Pastor, C., and Yubero, E.: Quantification of Saharan and local dust impact in an arid Mediterranean area by the positive matrix factorization (PMF) technique, Atmos. Environ., 42, 8872-8882, https://doi.org/10.1016/j.atmosenv.2008.09.018, 2008.

Notaro, M., Yu, Y., and Kalashnikova, O. V.: Regime shift in Arabian dust activity, triggered by persistent Fertile Cres- cent drought, J. Geophys. Res. Atmos., 120, 10229-10249, https://doi.org/10.1002/2015JD023855, 2015.

Novak, M., Zemanova, L., Voldrichova, P., Stepanova, M., Adamova, M., Pacherova, P., Komarek, A., Krachler, M., and Prechova, E.: Experimental Evidence for Mobility/Immobility of Metals in Peat, Environ. Sci. Technol., 45, 7180-7187, https://doi.org/10.1021/es201086v, 2011.

Obreht, I., Zeeden, C., Hambach, U., Veres, D., Marković, S. b., Bösken, J., Svirčev, Z., Bačević, N., Gavrilov, M. B., and Lehmkuhl, F.: Tracing the influence of Mediterranean climate on Southeastern Europe during the past 350,000 years, Sci. Rep., 6, 36334, https://doi.org/10.1038/srep36334, 2016.

Poore, R. Z., Quinn, T. M., and Verardo, S.: Century-scale movement of the Atlantic Intertropical Convergence Zone linked to solar variability, Geophys. Res. Lett., 31, L12214, https://doi.org/10.1029/2004GL019940, 2004.

Pop, E.: Mlaştinile de turbă din Republica Populară Română (Peat bogs from Romania), Editura Academiei Republicii Populare Române, Bucharest, 1960.

Poto, L., Gabrieli, J., Crowhurst, S., Agostinelli, C., Spolaor, A., Cairns, W. R. L., Cozzi, G., and Barbante, C.: Cross calibration between XRF and ICP-MS for high spatial resolution analysis of ombrotrophic peat cores for palaeoclimatic studies, Anal. Bioanal. Chem., 407, 379-385, https://doi.org/10.1007/s00216014-8289-3, 2014.

Ramanathan, V., Crutzen, P. J., Kiehl, J. T., and Rosenfeld, D.: Aerosols, Climate, and the Hydrological Cycle, Science, 294, 2119-2124, https://doi.org/10.1126/science.1064034, 2001.

Rasmussen, S. O., Vinther, B. M., Clausen, H. B., and Andersen, K. K.: Early Holocene climate oscillations recorded in three Greenland ice cores, Quat. Sci. Rev., 26, 1907-1914, https://doi.org/10.1016/j.quascirev.2007.06.015, 2007.

Reimer, P., Bard, E., Bayliss, A., Beck, J. W., Blackwell, P. G., Bronk Ramsey, C., Buck, C. E., Cheng, H., Edwards, R. L., Friedrich, M., Grootes, P. M., Guilderson, T. P., Haflidason, H., Hajdas, I., Hatté, C., Heaton, T. J., Hoffmann, D. L., Hogg, A. G., Hughen, K. A., Kaiser, K. F., Kromer, B., Manning, S. W., Niu, M., Reimer, R. W., Richards, D. A., Scott, E. M., Southon, J. R., Staff, R. A., Turney, C. S. M., and van der Plicht, J.: IntCal13 and Marine13 Radiocarbon Age Calibration Curves 0-50,000 Years cal BP, Radiocarbon, 55, 1869-1887, https://doi.org/10.2458/azu_js_rc.55.16947, 2013.

Revel, M., Ducassou, E., Grousset, F. E., Bernasconi, S. M., Migeon, S., Revillon, S., Mascle, J., Murat, A., Zaragosi, S., and Bosch, D.: 100,000 Years of African monsoon variability recorded in sediments of the Nile margin, Quat. Sci. Rev., 29, 1342-1362, https://doi.org/10.1016/j.quascirev.2010.02.006, 2010.

Roberts, N., Moreno, A., Valero-Garcés, B. L., Corella, J. P., Jones, M., Allcock, S., Woodbridge, J., Morellón, M., Luterbacher, J., Xoplaki, E., and Türkeş, M.: Palaeolimnological evidence for an east-west climate see-saw in the Mediterranean since AD 900, Global Planet. Change, 84-85, 23-34, https://doi.org/10.1016/j.gloplacha.2011.11.002, 2012.

Ross-Barraclough, F. and Shotyk, W.: Millennial-scale records of atmospheric mercury deposition obtained from ombrotrophic and minerotrophic peatlands in the Swiss Jura Mountains, Environ. Sci. Technol., 37, 235-244, https://doi.org/10.1021/es0201496, 2003. 
Rothwell, J. J., Taylor, K. G., Chenery, S. R. N., Cundy, A. B., Evans, M. G., and Allott, T. E. H.: Storage and behavior of $\mathrm{As}, \mathrm{Sb}, \mathrm{Pb}$, and $\mathrm{Cu}$ in ombrotrophic peat bogs under contrasting water table conditions, Environ. Sci. Technol., 44, 8497-8502, https://doi.org/10.1021/es101150w, 2010.

Rousseau, D. D., Chauvel, C., Sima, A., Hatté, C., Lagroix, F., Antoine, P., Balkanski, Y., Fuchs, M., Mellett, C., Kageyama, M., Ramstein, G. and Lang, A.: European glacial dust deposits: Geochemical constraints on atmospheric dust cycle modeling, Geophys. Res. Lett., 41, 7666-7674, https://doi.org/10.1002/2014GL061382, 2014.

Russell, J. M., Johnson, T. C., and Talbot, M. R.: A 725 yr cycle in the climate of central Africa during the late Holocene, Geology, 31, 677-680, https://doi.org/10.1130/g19449.1, 2003.

Sapkota, A., Cheburkin, A. K., Bonani, G., and Shotyk, W.: Six millennia of atmospheric dust deposition in southern South America (Isla Navarino, Chile), The Holocene, 17, 561-572, https://doi.org/10.1177/0959683607078981, 2007.

Scheuvens, D., Schütz, L., Kandler, K., Ebert, M., and Weinbruch, S.: Bulk composition of northern African dust and its source sediments - A compilation, Earth-Sci. Rev., 116, 170194, https://doi.org/10.1016/j.earscirev.2012.08.005, 2013.

Schnitchen, C., Charman, D. J., Magyari, E., Braun, M., Grigorszky, I., Tóthmérész, B., Molnár, M., and Szántó, Z.: Reconstructing hydrological variability from testate amoebae analysis in Carpathian peatlands, J. Paleolimnol., 36, 1-17, https://doi.org/10.1007/s10933-006-0001-y, 2006.

Schumacher, M., Schier, W., and Schütt, B.: Mid-Holocene vegetation development and herding-related interferences in the Carpathian region, Quat. Int., 415, 253-267, https://doi.org/10.1016/j.quaint.2015.09.074, 2016.

Shanahan, T. M., McKay, N. P., Hughen, K. A., Overpeck, J. T., Otto-Bliesner, B., Heil, C. W., King, J., Scholz, C. A., and Peck, J.: The time-transgressive termination of the African Humid Period, Nat. Geosci., 8, 140-144, https://doi.org/10.1038/ngeo2329, 2015.

Sharifi, A., Pourmand, A., Canuel, E. A., Ferer-Tyler, E., Peterson, L. C., Aichner, B., Feakins, S. J., Daryaee, T., Djamali, M., Beni, A. N., Lahijani, H. A. K., and Swart, P. K.: Abrupt climate variability since the last deglaciation based on a highresolution, multi-proxy peat record from NW Iran: The hand that rocked the Cradle of Civilization?, Quat. Sci. Rev., 123, 215230, https://doi.org/10.1016/j.quascirev.2015.07.006, 2015.

Shotyk, W.: The chronology of anthropogenic, atmospheric $\mathrm{Pb}$ deposition recorded by peat cores in three minerogenic peat deposits from Switzerland, Sci. Total Environ., 292, 19-31, https://doi.org/10.1016/S0048-9697(02)00030-X, 2002.

Shotyk, W., Krachler, M., Martinez-Cortizas, A., Cheburkin, A. K., and Emons, H.: A peat bog record of natural, preanthropogenic enrichments of trace elements in atmospheric aerosols since $12370{ }^{14} \mathrm{C} \mathrm{yrBP}$, and their variation with Holocene climate change, Earth Planet. Sci. Lett., 199, 21-37, https://doi.org/10.1016/S0012-821X(02)00553-8, 2002.

Smalley, I., Marković, S. B., and Svirčev, Z.: Loess is [almost totally formed by] the accumulation of dust, Quat. Int., 240, 4-11, https://doi.org/10.1016/j.quaint.2010.07.011, 2011.

Springer, G. S., Rowe, H. D., Hardt, B., Edwards, R. L., and Cheng, H.: Solar forcing of Holocene droughts in a stalagmite record from West Virginia in east-central North America, Geophys. Res. Lett., 35, L17703, https://doi.org/10.1029/2008GL034971, 2008.

Sweeney, M. R. and Mason, J. A.: Mechanisms of dust emission from Pleistocene loess deposits, Nebraska, USA, J. Geophys. Res. Earth Surf., 118, 1460-1471, https://doi.org/10.1002/jgrf.20101, 2013.

Swindles, G. T., Blundell, A., Roe, H. M., and Hall, V. A.: A 4500-year proxy climate record from peatlands in the North of Ireland: the identification of widespread summer "drought phases"?, Quat. Sci. Rev., 29, 1577-1589, https://doi.org/10.1016/j.quascirev.2009.01.003, 2010.

Swindles, G. T., Patterson, R. T., Roe, H. M., and Galloway, J. M.: Evaluating periodicities in peat-based climate proxy records, Quat. Sci. Rev., 41, 94-103, https://doi.org/10.1016/j.quascirev.2012.03.003, 2012.

Szakács, A., Seghedi, I., Pécskay, Z., and Mirea, V.: Eruptive history of a low-frequency and low-output rate Pleistocene volcano, Ciomadul, South Harghita Mts., Romania, Bull. Volcanol., 77, 12, https://doi.org/10.1007/s00445-014-0894-7, 2015.

Tanţau, I., Reille, M., De Beaulieu, J. L., Farcas, S., Goslar, T., and Paterne, M.: Vegetation history in the Eastern Romanian Carpathians: Pollen analysis of two sequences from the Mohos crater, Veg. Hist. Archaeobot., 12, 113-125, https://doi.org/10.1007/s00334-003-0015-6, 2003.

Tanţau, I., Feurdean, A., De Beaulieu, J. L., Reille, M., and Farcaş, S.: Vegetation sensitivity to climate changes and human impact in the Harghita Mountains (Eastern Romanian Carpathians) over the past 15000 years, J. Quat. Sci., 29, 141-152, https://doi.org/10.1002/jqs.2688, 2014.

Torrence, C. and Compo, G. P.: A Practical Guide to Wavelet Analysis, B. Am. Meteor. Soc. USA, 79, 61-78, https://doi.org/10.1175/15200477(1998)079<0061:apgtwa>2.0.CO;2, 1998.

Turner, T. E., Swindles, G. T., Charman, D. J., Langdon, P. G., Morris, P. J., Booth, R. K., Parry, L. E., and Nichols, J. E.: Solar cycles or random processes? Evaluating solar variability in Holocene climate records, Sci. Rep. 6, 23961, https://doi.org/10.1038/srep23961, 2016.

Újvári, G., Varga, A., Ramos, F. C., Kovács, J., Németh, T., and Stevens, T.: Evaluating the use of clay mineralogy, $\mathrm{Sr}-\mathrm{Nd}$ isotopes and zircon $\mathrm{U}-\mathrm{Pb}$ ages in tracking dust provenance: An example from loess of the Carpathian Basin, Chem. Geol., 304, 83-96, https://doi.org/10.1016/j.chemgeo.2012.02.007, 2012.

Varga, G., Kovács, J., and Újvári, G.: Analysis of Saharan dust intrusions into the Carpathian Basin (Central Europe) over the period of 1979-2011, Global Planet. Change, 100, 333-342, https://doi.org/10.1016/j.gloplacha.2012.11.007, 2013.

Varga, G., Cserháti, C., Kovács, J., and Szalai, Z.: Saharan dust deposition in the Carpathian Basin and its possible effects on interglacial soil formation, Aeolian Res., 22, 1-12, https://doi.org/10.1016/j.aeolia.2016.05.004, 2016.

Veron, A., Novak, M., Brizova, E., and Stepanova, M.: Environmental imprints of climate changes and anthropogenic activities in the Ore Mountains of Bohemia (Central Europe) since 13 cal. kyr BP, The Holocene, 24, 919-931, https://doi.org/10.1177/0959683614534746, 2014.

Vinkler, A. P., Harangi, S., Ntaflos, T., and Szakács, A.: A Csornád vulkán (Keleti-Kárpátok) horzsaköveinek kőzettani és geokémiai 
vizsgálata - petrogenetikai következtetések, Földtani Közlöny, 137, 103-128, 2007.

Vukmirović, Z., Unkašević, M., Lazić, L., Tošić, I., Rajšić, S., and Tasić, M.: Analysis of the Saharan dust regional transport, Meteorol. Atmos. Phys., 85, 265-273, https://doi.org/10.1007/s00703-003-0010-6, 2004.

Wanner, H., Solomina, O., Grosjean, M., Ritz, S. P., and Jetel, M.: Structure and origin of Holocene cold events, Quat. Sci. Rev., 30, 3109-3123, https://doi.org/10.1016/j.quascirev.2011.07.010, 2011.

Wedepohl, K. H.: The composition of the continental crust, Geochim. Cosmochim. Acta, 59, 1217-1232, https://doi.org/10.1016/0016-7037(95)00038-2, 1995.

Wulf, S., Fedorowicz, S., Veres, D., Łanczont, M., Karátson, D., Gertisser, R., Bormann, M., Magyari, E., Appelt, O., Hambach, U., and Gozhyk, P. F.: The "Roxolany Tephra" (Ukraine) - new evidence for an origin from Ciomadul volcano, East Carpathians, J. Quat. Sci., 31, 565-576, https://doi.org/10.1002/jqs.2879, 2016.
Yoshioka, M., Mahowald, N. M., Conley, A. J., Collins, W. D., Fillmore, D. W., Zender, C. S., and Coleman, D. B.: Impact of desert dust radiative forcing on sahel precipitation: Relative importance of dust compared to sea surface temperature variations, vegetation changes, and greenhouse gas warming, J. Clim., 20, 14451467, https://doi.org/10.1175/JCLI4056.1, 2007.

Yu, S.-Y.: Centennial-scale cycles in middle Holocene sea level along the southeastern Swedish Baltic coast, Geol. Soc. Am. Bull., 115, 1404, https://doi.org/10.1130/B25217.1, 2003. 